\title{
CORPORATE BRANDING AND VALUE CREATION FOR INITIATING AND MANAGING RELATIONSHIPS IN B2B MARKETS
}

\begin{abstract}
Purpose

This study aims to fill a gap in branding literature concerning the effect of corporate brand relationships on brand value through the case study method in a business-to-business (B2B) context. The objectives of this study can be framed in three questions: (1) what are the main constituents of a corporate brand; (2) how does a corporate brand generate tangible and intangible brand value for their business customers; and (3) how do tangible and intangible brand benefits influence relationship initiation and management practices of the case companies?
\end{abstract}

\section{Design/methodology/approach}

The study adopts a qualitative multiple case study design by using archival data, and both indepth telephone and online interviews with senior representatives of the case study companies to investigate corporate branding and associated issues in a B2B context.

\section{Findings}

From a managerial perspective, this study reveals that corporate business culture, brand relationships, products, and corporate identity and personality as the main constituents of a corporate brand in a $\mathrm{B} 2 \mathrm{~B}$ context. The results show that a corporate brand can generate intangible and tangible brand value benefits for business customers. The findings also note the importance of the brand value in enhancing relationship initiation.

\section{Originality/value}

The study contributes to the branding literature by developing a conceptual model that explains the development and role of the corporate brand in a B2B context with its associated value creation and brand management outcomes. The findings advance brand management literature on business relationships, which addresses a gap in B2B contexts rather than mainly about product brand management and value creation in B2C contexts.

Keywords: Corporate brand; Corporate brand relationships; business-to-business; brand value; relationship initiation; relationship management 


\section{Introduction}

This paper examines the use of business relationships for establishing a corporate brand and identifies its constituents. Successful corporate brand management can reduce the high costs of initiating and maintaining customer relationships by establishing favourable dispositions to the company, and sending signals to stakeholders about the corporate brand and the values it delivers (Kernstock and Brexendorf, 2009). Past studies have not yet identified the importance of understanding the benefits of value-creation during corporate branding efforts to reduce the efforts required for relationship initiation and maintenance or management from a supplier's perspective (Gupta et al., 2016; Valtakoski, 2015). For instance, Ryan and Silvanto (2013) examined the role of corporate branding in enhancing brand loyalty from a business customer's viewpoint, which is also related to the maintenance rather than initiation of business-tobusiness (B2B) relationships. From a supplier perspective, the process and efforts in corporate branding in both relationship initiation and relationship maintenance may provide insights into issues influencing customer perceptions. Few studies have examined brand value in a B2B context (e.g. Vallaster and Lindgreen, 2011) and hence, the present study explores how different types of corporate brand value, including tangible (i.e. functional) and intangible (i.e. emotional) value can be generated in B2B marketing relationships. Moreover, more emphasis is given to communicate the functional benefits of a brand in $\mathrm{B} 2 \mathrm{~B}$ relationships but with scant research attention on intangible or emotional aspects (Mudambi, 2002). Thus, the present study attempts to address this gap by examining the role of corporate branding in enhancing different types of brand value, and its effect on B2B relationship initiation and maintenance strategies.

Within B2B marketing, a business customer is more likely to be concerned with the role of a supplier's corporate branding in influencing its image on the market (Kaufmann et al., 2015; Simoes et al., 2015). Consequently, the evaluation of a corporate brand and its role in B2B marketing with businesses is different from B2C marketing, where a business deals directly with individual consumers. Corporate branding requires consideration downstream customer needs such as distributors and retailers, which serve upstream suppliers in terms of creating added business value through business relationships (Nyadzayo, Matanda and Ewing, 2013). The study contributes to the corporate branding literature through the case study research of companies.

Specifically, this study has three inter-related objectives. The first is to identify the constituents 
of a corporate brand by examining and differentiating between internally and externally derived business relationships of the firm. Secondly, the study explores how a corporate brand can produce diverse types of brand value, which would help the study to conceptualise a typology of tangible and intangible value benefits generated by a corporate brand. Finally, the study analyses the relationship initiation and management implications of value creation for corporate branding.

In the following sections we draw on researches on corporate branding in B2B marketing to develop the conceptual framework and propositions of the study. the This is followed by the research methodology and findings sections. The paper concludes with a discussion of the theoretical significance of corporate brands in B2B and its implications for industries for business champions.

\section{Theoretical background and conceptual model}

Corporate branding constructs can be viewed to have applicability to entire organisation e.g. HSBC Bank, subsidiaries, e.g. Vauxhall as a subsidiary brand of Ford, to nation-states e.g. Italy, cities e.g. Sydney, to alliance-brands e.g. Airline alliances of OneWorld and to supranational organisations e.g. the Olympics (Balmer, 2001; 2005; 2013). Corporate brands are marshalled by individuals and groups to define who they are - and demonstrates the unique identity of a corporation, including what it offers in terms of products or services as well as showing its corporate values.

Corporate branding is related to the multiple stakeholders interacting with the organisation's employees such as shareholders, media, competitors, governments and many others to build and maintain positive perceptions, thus gaining competitive advantage (Foroudi et al., 2019; Roll 2004). An advantage of corporate branding is the opportunity for achieving a coherent focus for all products and conveying consistent messages to all stakeholders (Riley and de Chernatony 2000). Yet, there is a perception of a gap in the branding literature that concerns the effect of a corporate brand in a B2B context. The literature in domains ranging from $\mathrm{B} 2 \mathrm{~B}$ relationships (Kernstock and Brexendorf, 2009), brand identity (Ballantyne and Aitken, 2007; Törmälä and Gyrd-Jones, 2017) and in strategic multi-disciplinary applications (Varadarajan, 2010) have tried to delineate how firms, or the "people behind the brands" (Bhattacharya and Sen, 2003, p. 76) can develop deeper, more committed associations with businesses and turn them into champions. 
However, despite the significance of corporate branding in the B2B marketing literature the majority of studies e.g. Harris and Chernatory (2001); Hatch and Schultz (2001); Knox and Bickerton (2003); Schultz and Hatch (2003) are focused on the constituents of a corporate brand, which have been conceptual rather than empirical and with little distinction of their use in B2B and B2C markets. Even though there are important examples of corporate brands that are influencing or changing the B2B industries, they are in from the longer established IBM Business solutions to the newer AWS (Amazon Web Services). The strategic vision is key to embody and express top management's aspiration for what the company will achieve in the future. There are also those that started out looking for support in B2B markets going on to the B2C marketplace e.g. Dyson for his iconic DC07, the first bagless vacuum cleaner that went on to gain iconic consumer status. Initially rejected by B2B company managers who thought their consumers would not be prepared to buy a cleaner that displayed dirt, Dyson marketed it under his own name in the B2C marketplace (Fortune, 2019).

Business-to-business or its modernised short form of B2B, covers businesses where marketing is dedicated to those making purchases on behalf of their organisations with other organisations or other smaller entities, e.g. software and design agencies. This is in contrast to B2C, where businesses have transactions directly with end consumers e.g. individuals and families. Corporate brands that are not only adopted in industries, such as Apple's iconic products Apple's Mac computers iPhones and iPads, transcend such boundaries being sold to businesses and individuals directly. Therefore, limitations of the literature bound to conceptual descriptions rather than empirically distinguishing corporate branding in $\mathrm{B} 2 \mathrm{~B}$ markets raises questions. These are about: (1) what the main constituents of a corporate brand in a B2B context are; (2) how a corporate brand can generate tangible and intangible brand value for a business customer; and (3) what tangible and intangible benefits of brands might influence relationship initiation and management practices of the case companies in a study? These questions generated from the literature have helped to form the objectives for this paper.

As the concept of corporate brand management is broad and is multi-disciplinary in scope, the following sections will review what the main constituents of a corporate brand might be, how a corporate brand may generate tangible and intangible brand value for its business customers and how tangible and intangible brand value benefits of corporate branding may relate to relationship initiation and management practices in a $\mathrm{B} 2 \mathrm{~B}$ context. 


\section{From Corporate Business Culture to Corporate Brand}

The business culture, which represents an organisation's shared values, beliefs, attitudes and behaviours, acts as a guiding principle for brand management and all other corporate decisions (Anees-ur-Rehman et al, 2017; Balmer, 1995; Hatch and Schultz, 2001). It provides the context in which employees interact with each other and with other stakeholders such as business customers, suppliers and distributors (Balmer and Greyser, 2006). Baumgarth and Schmidt (2010) used a survey method to examine how B2B brands create and deliver value for firms in inter-organisational transactions. Their study finds that effective business-to-business branding depends on a brand-oriented corporate culture. On the other hand, Sarkar and Mishra's (2017) study, which examined dyadic relationships between business firms from survey data, could not find any support regarding the effect of a market-oriented culture on a corporate brand's equity. This finding can be attributed to the fact that the study does not consider the mediating impact of the corporate brand, which could be influenced by market orientation culture and in turn affect the corporate brand equity.

Overall, while both Baumgarth and Schmidt (2010) and Sarkar and Mishra's (2017) studies lack empirical evidence on how overall corporate culture may affect a corporate brand, most of the studies examining the issue are conceptual in nature. This is even though an ambiguous corporate culture may jeopardise a corporate brand (Hatch and Schultz, 2001). For example, the main problem of new enterprises in building a corporate brand is that since they lack a shared value base, history or culture, they are more receptive to external influences compared to well-established organisations (Tormala et al., 2017). In this sense, corporate culture enhances the credibility of a corporate brand against external influences by means of established history and value proposition (Balmer, 2012). This is particularly important in a B2B context in which undesirable or misaligned corporate values, culture and brand of partner firms may affect the corporate image and performance of business firms in the marketplace. Managers are responsible for creating conducive cultures and demonstrating their sincerity to their organisations' vision to share the passion (Balmer, 2005) representing collectively, internal stakeholders' feelings such as their beliefs, values and assumptions. The biggest obstacles to incorporation are un-sympathetic cultures and disinterested managers. Brand values will only be embraced if managers are eager to share the organisational vision and demonstrate that they are genuine in their promises and commitment (Hatch and Schultz, 2008). Hence, 
Proposition 1: Building of a corporate brand for business markets depend upon the business culture of the corporate.

\section{Brand Relationships to Corporate Brand}

Success in B2B corporate branding truthfully originates from the aptitude to create genuine relationships encouraged as partnerships rather than retailer businesses - between internal and external, current and future customers or partners (Erevelles et al, 2008). Although the significance of relationship building is something frequently connected with B2C corporate brands, it is more dominant for B2B corporate brands (Čater and Čater, 2010). B2B corporate brands are based on relationships and they must be content with the give and take any relationship necessitates because they signify future relationships beyond the instant purchases (Paparoidamis et al, 2017).

Previous scholars (Balmer and Greyser, 2003; De Chernatony and Segal-Horn, 2003; Hatch and Schultz, 2008; Ind and Bjerke, 2007; Schultz and De Chernatony, 2002) recognised the noteworthy expansion in the conceptualisation of corporate branding from the all-embracing stakeholder approach. A stakeholder approach results from the ways a corporate brand can meet stakeholders' benefits, concerns and long-term well-being requirements, as with B2C marketers generally discussing 'brand and customer' relationships. A widely used framework in the corporate branding literature is Hatch and Schultz's (2001) Vision-Culture-Image model since it defines a successful corporate branding process as the alignment of strategic vision, organisational culture and stakeholder images. Organisational culture refers to the internal values, beliefs and underlying assumptions that embody the heritage of the company and is manifested in the ways that employees feel about the company they are working for. Corporate image defined by the previous studies (Ageeva et al., 2018ab; Foroudi et al., 2014; 2016; 2018) as is the immediate mental picture an individual holds of the organisation. It can materially affect individuals' sense of association with an organisation and is likely to have an impact on behaviour which cannot be controlled by the companies. The concept of corporate image projected through the corporate identity and represents for the organisation the view of it as seen by its external stakeholders (external world's) overall impression of the company including the views of customers, shareholders, media and the general public (Hatch and Schultz, 2001; Hatch and Schultz, 2003, Hatch and Schultz, 2015). Though the Vision-CultureImage model has been a useful framework to understand the concept of corporate branding, to 
fully understand the successful implementation of the concept in a B2B marketing setting, there is a need for further identification of its constituents e.g. customer attachments to brands, perceived brand value benefits and B2B relationship implications in business markets.

Earlier studies identified three levels of relationships among the corporate brand and internal stakeholders as (i) compliance (Kapferer, 2001; Karmark, 2005; Kotler and Pfoertsch, 2006; Lencioni, 2002), (ii) identification (Alvesson and Willmott, 2002; Berthon et al., 2009; Burmann and Zeplin, 2005; Dutton et al., 1994), and (iii) internalisation (Burmann and Zeplin, 2005; Chong, 2007; Morhart et al., 2009). Compliance is the lowest level of emotional commitment with sympathy for internal stakeholders' aligning to a company's corporate brand, where they only follow the company's 'brand rules' principles (Lencioni, 2002). At compliance level, employees submit with very elementary brand expectations and exhibitions on-brand behaviour, which Karmark (2005) called as 'living-by-the-brand'.

Identification is the next level of emotional relationship between internal and external stakeholders which is more comprehensive. Burmann and Zeplin (2005) stated this extensive relationship accumulated when a key level of corporate brand identity congruity among the stakeholders and the brand has been created. According to Dutton et al (1994), brand recognition improves stakeholders' self-esteem, self-expression and self-concept in social interactions. Internalisation is the main and highest level of relationships among stakeholders and corporate brands. When a stakeholder buys into the brand, he or she adopts the company's values, corporate identity and what the brand stands for, in comprehensive congruity with his or her behaviour (Ind, 2004). This state of attitudinal and emotional alignment can be categorised with different terms such as 'brand citizenship', 'brand ambassadorship', and 'brand championship' (Burmann and Zeplin, 2005; Morhart et al, 2009). Brand managers are thus being challenged to (i) increase their opinion of brand relationships to deliberate a range of diverse stakeholders where brand value is created and (ii) to assess and put a value on the worth of the relationships. Based on the corporate branding paradigm, brand relationships with internal stakeholders are the main sources of value to create meaning and identity for employees, helping them to improve productivity and motivations (Veloutsu and Moutinho, 2009) and giving a sense of purpose to their work. To explore how and to what extent B2B companies empower their relationships with external and internal stakeholders to develop a genuine corporate brand we propose, 
Proposition 2a: Building of a corporate brand for business markets depends upon the strength of relationships it has with its internal stakeholders.

Proposition 2b: Building of a corporate brand for business markets depends upon the strength of relationships it has with its external stakeholders.

\section{Corporate Personality and Corporate Identity to the Corporate Brand}

Corporate personality is defined as the total sum of the characteristics of a company including intellectual and behavioural characteristics that serve to distinguish one organisation from another (Abratt, 1989; Melewar et al., 2017; Foroudi et al., 2019) such as a corporate brand's individual character (Urde, 2013; Urde and Greyser, 2015). Corporate personality traits of an efficient organisation refer to its 'heart' (passion and compassion), 'mind' (creativity and discipline) and 'body' (agile and collaborative) to guide employees with impact on how it will be seen by others. These factors influence corporate identity (Olins, 1978).

Corporate identity is the features, characteristics, traits or attributes of a company that are presumed to be central, distinctive and enduring and serves as a vehicle for expression of the company's philosophy, values, and mission, communications; and corporate visual identity to all its audience (Balmer, 2001; Barnett et al., 2006; Foroudi et al., 2019; 2020; He and Balmer, 2007). The concept of corporate identity is more self-constructed and controlled by the organisation. Corporate identity can be observed as branding at the corporate-level (Foroudi et al, 2017). According to Ind (1997) "a corporate brand is more than just the outward manifestation of an organisation with its name, logo and visual presentation. Rather it is the core of values that defines it" (p.13). Communication can shape the connection between a company's personality and identity (Melewar et al., 2017) and companies communicates a reliable message and the personality of the brand to the target audience and customers globally (eg., Foroudi, 2019). Also, consumers prefer the products corresponding with their image, and they express their personality or characteristics through the products corresponding with their self-image (Foroudi et al., 2017; 2018; Tourky et al., 2020).

Previous scholars (Balmer, 2001; Balmer and Gray, 2003; Foroudi et al., 2019; 2020; Knox and Bickerton, 2003; McDonald et al, 2001, Simoes et al, 2005) recognised the organisation as a brand in its entirety and the organisation as a strategic component in branding, illustrating an opportunity to include a corporate's core values among its strategic selling-points (Hatch and 
Schultz, 2000, 2003; Urde, 2003). Core values (Urde, 2009) and a branding concept can be directly applied at the corporate level (Aaker, 1996; Ind, 1997). In addition, A study by Melewar et al. (2017) found that company-consumer connections ought to concentrate on conveying buyers personally with the hierarchical identity through co-creation activities.

Corporate brand identity is a complex concept which incorporates internal and external stakeholders (Burmann et al, 2009) to refer to "the features, characteristics, traits or attributes of a company that are presumed to be central, distinctive and enduring" (He and Mukherjee, 2009 , p. 2). Corporate identity can be defined as 'what are we?' which can encompass referring to "what is our business, structure, strategy, ethos, market, performance, history, reputation, and relationships to other identities?" (Balmer, 2001, p. 257; Gioia et al, 2000). Corporate identity management encompasses the self-motivated interactions between a company's corporate strategy, corporate culture, corporate design, including the philosophy of the company's executives. The collaboration of these features results in distinguishing the company from other competitors making the 'corporate brand' distinctive or a key marketing metaphor (Gray and Balmer, 1998). Given that a company's corporate identity and its key components (philosophy, vision, value and positioning) are more likely to impact the favourability of a B2B company's corporate brand in a business market, the following are proposed,

Proposition 3: Building of a corporate brand for business markets depends upon the identity of the corporate.

Proposition 4: Building of a corporate brand for business markets depends upon the personality of the corporate.

\section{Product Brand and Corporate Brand}

The concept of corporate brands have used by brand management scholars (de Roeck et al., 2013; Iglesias et al., 2019; Ind et al., 2013) and used in the context of B2C (business-toconsumer) (Merrilees, 2007) and B2B (business-to-business) (Beverland, Napoli, \& Lindgreen, 2007; Mudambi, 2002). Iglesias et al. (2019) defined as corporate brands the stakeholder focus brand era'. Based on the above definition, the key difference is corporate brands focus on multiple stakeholders, however, product brands concentration only on customers. Successful corporate brand management has responsibility for a product brand and 
requires consistent communication of a corporate brand's constituents, including its products (Foroudi et al., 2017). According to Balmer and Gray (2003), the product brand is mainly recognised as the marketing communications mix, whereas the corporate brand is recognised as the total corporate communications mix. Some authors, managers, and consultants regard corporate identity and corporate brand as equivalent terms, whereas many others fail to make a distinction among corporate brands and product brands. Balmer (2001) and Balmer et al. (2013) differentiated these two concepts. There is a delivering of the promised product quality, particularly in terms of reliability and consistency over time. These are essential to enhance an business customer's commitment (Čater and Čater, 2010). Concerning this, the consistent communication of the product benefits and delivering expected product provision and quality can improve the satisfaction of business customers (Chernatony and Segal-Horn, 2000). Fetscherin and Usunier (2012) point out the importance of corporate advertising of products in influencing the positioning of a corporate brand.

Product branding research in the B2B context explains tangible benefits as functional characteristics associated with physical products, such as their properties, prices and performances (Elsäßer and Wirtz, 2017; Kuhn et al, 2008; Leek and Christodoulides, 2012; Mudambi, 2002). Intangible benefits stem from the emotional value attained by using a product brand, such as its reputation and image (Lai et al, 2010; Lynch and Chernatony, 2004; Mitchell et al, 2001; Mudambi, 2002), reassurance (Lynch and Chernatony, 2004) and association (Lai et al., 2010). However, a corporate brand requires evaluation of tangible or functional characteristics and intangible or emotional characteristics at the wider corporate level. Though, the corporate branding and product branding literature are comprehensive in scope and explained by previous authors (Balmer, 2001; 2013; Balmer et al., 2013), there is a lack of clarity, thus,

Proposition 5: Building of a corporate brand for business markets depend upon products offered by the corporate.

\section{Corporate Brand and Brand Value}

Leek and Christodoulides (2012) argued that while B2C brand management requires emphases on tangible i.e. functional and intangible i.e. emotional benefits of brands, B2B brand management gives greater customer emphasis on risk-reduction and less customer emphasis on intangible or emotional benefits (Mudambi, 2002). More recent studies (Candi and Kahn, 
2016; Leek and Christodoulides, 2012) find that although business customers are mostly seen as the 'rational buyers' evaluating a brand based on its tangible brand value benefits that are more functional in nature, the supplier selection may also be strongly influenced by intangible emotional factors. Yet, these studies have focused on brand value implications of business product or service brands rather than corporate brands, the latter of which is evaluated more comprehensively at the corporate level. In particular, corporate branding research is limited in providing a categorisation of different types of brand value as opposed to product branding research (Balmer and Gray, 2002). The concept of brand value is conversationally developed by various stakeholders in the organisation to continuous co-operation and frequently progresses beyond an organisation' strategic objectives set by brand managers (Iglesias et al, 2013). An organisation's brand value can be reproduced in the good-will element of the corporate brand. For instance, employees could relate their preferences associating with their organisation's corporate brand via their work engagements, customers could be referred to their preferences concerning a corporate brand compared to others and business partners could relate a desire to be allied with a corporate brand in the context of B2B marketing (Iglesias et al., $2013 ; 2017)$.

Corporate branding research is limited in providing a typology of different types of brand value as opposed to the product branding research. The studies on corporate branding refer to tangible assets or resources and intangible assets or resources (Balmer and Gray, 2002). While tangible assets of a corporate brand have been explained as the financial value of the corporate (Balmer and Gray, 2002), intangible assets have been related to the perceptions, beliefs and experiences of customers (Balmer and Gray, 2002) and explained as a corporate's credibility and reputation (Hur et al., 2014) and image (Elsäßer and Wirtz, 2017). However, this study explains the value benefits of a corporate brand as the benefits provided to customers. This approach is different from the previous studies which defined the tangible assets of corporate brands in terms of supplier-related value benefits.

In a corporate brand context, Kuhn et al, (2008) applied Keller's model in the B2B context and emphasised the limitations of the theory in terms of ignoring the elements or constituents related to support services e.g. the rapport between the service provider and customer and the after-sales support and the firm e.g. profitability, market share and reputation. These are more important in B2B relationships than B2C in generating a brand's value. Based on semistructured interviews with senior buyers of technology for the electronic tracking of waste 
management, their study showed that organisational buyers gave greater emphasis to the corporate brand than on individual product brands in the evaluation of overall brand value. However, we assume that at the corporate level, corporate brands will contribute to the total value by generating different types of brand value for business customers including tangible benefits related to their cognitive or functional evaluations of using a corporate brand (Silva and Alwi, 2008) and intangible benefits associated with their emotional value of using the corporate brand (Mason and Simmons, 2013). Hence,

Proposition 6a: A corporate brand offers tangible benefits as brand value to its customers in business markets.

Proposition 6b: A corporate brand offers intangible benefits as brand value to its customers in business markets.

\section{Brand Value and Relationship Initiation}

During the B2B relationship initiation stage, firms such as suppliers and customers develop an initial familiarity with each other and form expectations about future interactions by seeking instrumental values (Chen et al, 2011). In a B2B branding context, suppliers can create expectations of their customers by communicating the value promises of their corporate brands. For example, business customers would initially evaluate whether the tangible value benefits of a supplier's corporate brand e.g. brand competence, economic benefits, assurances are likely to support their firms' business performances and profitability (Kuhn et al., 2008). Thus, suppliers can take advantage of the tangible benefits of their corporate brands to initiate relationships with their customers. However, intangible value benefits of a supplier's corporate brand would also be important for a business customer's decision and need to complement tangible benefits, to increase the odds of relationship initiation.

Particularly, when customers do not have any prior familiarity with a supplier they are likely to seek some intangible value benefits e.g. brand name, brand reputation and brand image about a supplier's corporate brand to form emotional associations. To nurture their feelings of trust and reduce their concerns on the potential opportunistic behaviour in the B2B relationship, suppliers need to support their relationship initiation decisions by building and communicating the intangible benefits of their corporate brands (Wathne and Heide, 2000). Relationship initiation management, on the other hand, is about building and maintaining relationships of 
mutual value between firms (Payne and Frow, 2004). In a B2B context suppliers need to ensure that the value promises of their corporate brands are realised in the actual customer experience. For example, tangible benefits of their corporate brands would support business customers in terms of obtaining sustainable business performance. Similarly, intangible benefits obtained through the B2B relationship, such as being associated with a supplier's reputable corporate brand would contribute to their image in the marketplace. Therefore:

Proposition 7a: Brand value from tangible benefits offered by a corporate brand, initiate relationships with customers in business markets.

Proposition 7b: Brand value from intangible benefits offered by a corporate brand, initiate relationships with customers in business markets.

\section{Research method}

\section{The case study method}

This research adopted a multiple case study approach using a qualitative research design as an appropriate research design to investigate and explore a contemporary phenomenon within specific organizational contexts (Eisenhardt, 1989; Yin, 2014). This study used a multiple case study approach since "with multiple cases, the authors set an appropriate level of abstraction i.e. probes, that were more accurate than the individual instantiations e.g. alliances, exploratory products" (Eisenhardt and Graebner, 2007, p. 27). In line with the recommendation of Eisenhardt and Graebner (2007) and the practice of several qualitative researchers (e.g. Brito, 1999; Zou and Ghauri, 2010), the study analysed three cases (IBM, Ogilvy and Mather, and UPS) to achieve sufficient analytical power. As Eisenhardt (1989) recommends, the number of cases were added and thus interviews continued until "theoretical saturation" was reached. Though this study included data collection from only a few cases, it is widely agreed that the validity, meaningfulness and insights attained through qualitative inquiry predominantly relies on the information richness of the selected cases rather than the sample size of a study (Patton, 1990).

In qualitative research, sample size has long been debated and the literature (Creswell, 2014; Wright and Wright, 2017) is clear that it is necessary to collect data to provide sufficient insights from a qualitative study using a sample much smaller than that required for a quantitative study. The three cases enable the propositions to be researched given that when 
exploring meanings through interviews, a larger number does not necessarily provide more significant information due to the law of diminishing returns when what is collected is sufficient to make decisions. The objective of uncovering perceptions and information from interviews from three well known corporate brand entities avoided using a larger sample where data may become repetitive and superfluous.

\section{The case study firms}

The study focuses on monolithic, global and established brands to explore the concept of corporate branding in the $\mathrm{B} 2 \mathrm{~B}$ context, its main constituents, which can generate tangible and intangible brand value benefits for their business customers. These types of organizations give special emphasis to corporate branding with the objective of creating consistent brand positioning in different national boundaries. We selected IBM, Ogilvy and Mather, and UPS as the case study companies since all these three firms have been changing their corporate branding strategies within the last decade.

Moreover, there is interconnectivity between the three firms as Ogilvy and Mather (2019) has consulted and delivered advertising for both IBM and UPS. Their brand names and corporate identities are recognisable for what they do. The brand name of Ogilvy and Mather is frequently represented in the top advertising echelons in advertising. Globally, UPS as a world-wide carrier and deliverer and IBM as a top deliver of IT solutions for businesses are clear industry leaders, and both have services that each have used. The three cases give a foundation to consider endogenous (internal managerial) reflections about corporate brand identities and values and exogenous factors (external influences from markets and customers) that affect relationships proposed in our model stemming from new ones to those with already embedded relationships (Jap and Anderson, 2007) and power and dependence relationships (Johnsen and Lacoste, 2016) between suppliers and customers.

\section{IBM}

The roots of IBM date back to 1911, the establishment of its precursor, the ComputingTabulating-Recording Company (CTR) (IBM.com, 2017). In 1924, the company's name changed to International Business Machines Corporation (IBM), that has become one of the world's most prominent technology and business consultancy companies. The most significant turning point of the company has been its transition from being a PC hardware producer to a business consultancy company following the sales of PC business to Lenovo and acquisition 
of PW, Price Waterhouse Consulting in 2005 (IBM.com, 2017). Since then, IBM has gone through a significant re-positioning from being a PC producer to business consulting services provider. The switch from hardware to software and services provider has caused several essential changes and significant emphasis on the company's corporate brand strategy. Despite the considerable challenge of changing business lines the company has managed to be a high valued corporation in the field of business consultancy and system integrator (Gupta et al., 2014).

Today following Microsoft, IBM is the second most valuable B2B brand in the world (B2B Marketing, 2016). However, the main issue with the IBM brand is its detachment from the millennials as a mature megacompany. Thus, IBM is in an attempt to re-design its branding strategies to position itself against its major competitors such as Apple which have more contemporary positioning in the marketplace (Lyons, 2017). Such a continuous reinvestment enables IBM to stay relevant to the needs of the day which also requires continues investment in its corporate branding strategy, making it as one of the ideal case study companies for this study.

\section{Ogilvy and Mather}

Ogilvy and Mather (Ogilvy) name came into the advertising sector in 1965 though the agency was initially founded in 1948 by David Ogilvy with the name of Hewitt, Ogilvy, Benson, and Mather. The agency initiated its life as a micro-business, but today it has more than 450 offices in 169 cities. Today Ogilvy is one of the eight largest advertising networks in the world (Ogilvy.com, 2017). At the core of Ogilvy's corporate brand is the underlying notion that 'Good Branding is about stirring emotions. It sits in people's minds and has an attachment to the heart' (Ogilvy.com, 2005). This requires a creative flair to cultivate and embed emotive connections in the minds of an increasingly demanding cohort of consumers. An entrenched principle of Ogilvy is that the salient function of marketing communications is to sell and that the successful marketing of any product, irrespective of the communication channel, requires insights into consumers (Balmer, 2014). As such, Ogilvy uses brand audits as a proprietary research tool to capture consumers' perception of the brand.

Ogilvy and Mather have been going through significant changes in recent years in terms of their corporate branding strategy. In previous years, the Ogilvy brand was excessively engaged 
in sub-branding e.g. Ogilvy Prime, Ogilvy Noor. Neo@Ogilvy, Hogarth \& Ogilvy, Social@Ogilvy. These have created challenges in communicating single global brand identities and a global brand. Thus, the organisation is in the process of simplifying the brand by combining diversified sub-units under a single Ogilvy brand to give a specific focus on its corporate branding strategy (Stein, 2017). Ogilvy has an advantage of having tacit skills in brand strategy development and implementation given the agency's history of providing services ranging from advertising and public relations to branding consultancy, making it as a highly attractive and relevant case for this study.

\section{UPS}

As a company participating in B2B relationships globally, United Parcel Service (UPS) was founded in 1907 as a messenger company and has later refurbished itself to become a corporation which is 'focusing on the goal of enabling commerce around the globe' (USP.com, 2017). UPS went public in 1999 in the largest IPO of the 20th century and the following two years made 25 acquisitions that enhanced its capabilities in areas like customs brokerage, critical parts logistics, freight forwarding, retailing and financial services (Kuehn Nov, 2004). Subsequently, in 2003, UPS undertook a massive marketing strategy that was centred on rebranding and realigned itself around a new brand promise (Park et al., 2016; USP.com, 2017). After its massive re-branding, UPS gave itself a face-lift with a new logo, new services and a new image (Park et al, 2016).

Today UPS is the largest package delivery company in the world and the 'leading global provider of specialized supply chain management and logistics services' providing the flow management of goods, funds and information worldwide (Park et al., 2016). Recently, it is ranked as the most valuable B2B logistics brand and the fifth most valuable B2B brand, well ahead of its closest competitor, FedEx which is ranked as the fifteenth (B2B Marketing, 2016). This success can be attributed to the company's repositioning as a business-to-business solution for companies with logistical considerations which are more complex than just collecting and delivering parcels (Beltrone, 2015). Over the years the company has continued to make significant investments in its branding strategy to communicate its new identity and value proposition which makes it a valuable case study company to investigate.

\section{Data collection: technique and process}

The data collection of this study included both archival and interview data. The archival data 
included the analysis of the media, company reports, company websites, newspapers, magazines, autobiographies, etc. The archival data was triangulated using the in-depth telephone and online interviews with senior representatives of the case study companies. The interviews were undertaken between April and June 2017 and lasted between 60 and 120 minutes (Table 1). The interviews employed multiple respondent techniques to reduce any potential subjectivity and biases (Eisenhardt and Graebner, 2007). Two respondents were interviewed from each case study company. The respondents were selected based on their knowledge of the corporate branding strategies of their firms, their experiences and direct involvements with business customers. In IBM and UPS cases the respondents from senior management teams, including the marketing and business development managers, were interviewed. In the Ogilvy case the interviews were conducted with the senior creative directors. The respondents were asked some semi-structured and probing questions to explore the themes such as the constituents of corporate branding and the determinants of corporate branding in B2B e.g. their impact on brand value benefits (see Table1). We kept the questions intentionally broad to permit the interviewees as much depth and freedom in their answers as possible.

Purposeful sampling method was used to identify and select the case study firms. This method enabled the researchers to make a judgement in choosing the case study companies to address the theoretical objective and research questions of the study. This sampling method has allowed us to study informative cases to gain insights and deep understandings of the phenomenon being investigated (Patton, 2002). When selecting the case study companies and individual respondents, we used the Maximum Variation Sampling method of purposeful sampling strategy to capture any potential industrial variations of the corporate branding strategies across and regional variations within companies (Suri, 2011). Since in maximum variation sampling, "any common patterns that emerge from great variation are of particular interest and value in capturing the core experiences and central, shared dimensions of a setting or phenomenon" (Patton, 2002, pg. 235), as suggested by Patton (2002), this study maximized the variation in its small sample by enhancing their industrial and geographical variation.

Respondents were approached by e-mails and phone calls to explain the purpose of the study and invite them to interviews. The respondents had at least ten years of industry experience and represented four different countries: India, Germany, Turkey, and United Arab Emirates. 


\section{$<<<$ Insert Table 1 Here $>>>$}

\section{Findings}

Gaining a greater understanding of corporate branding in the B2B context, the findings of the in-depth interviews from the three cases uncovered current problems and adjustments as to how the three corporate organisations adapted to the dynamics of change. Concerning supporting literature, a review of sources had shown that the concept of the corporate brand and its main constituents and relationships were not well explored. This gap in the literature helps to identify what important research constructs are to be applied in the study for this paper. The proposed model in Figure 1 is designed based on reviewing the literature from multidisciplinary, archival and qualitative research approaches.

Designing a management's level conceptual framework that is recognisable for corporate branding theory illustrates the need for: (i) building a corporate brand for business markets that is dependent upon an organisation's brand identity, personality, relationships among internal and external stakeholders inherent in its business culture; (ii) offering a corporate brand with tangible and intangible benefits on a brand value platform to its customers in business markets; (iii) initiating corporate brand relationships with business customers who perceive and receive recognisable value benefits; and (iv) reinforcing the relationships between other theoretically recognized variables. Figure 1 is a visual model that is proposed to demonstrate the various components in the boxes and what are the interrelationships are to each other.

\section{$<<<$ Insert Figure 1 Here $>>$}

\section{Corporate Business Culture and the Corporate Brand}

Business cultures of the case study companies have been and are highly influential in building their corporate branding. For example, UPS creates positive impressions about its corporate branding by adopting a sustainability culture i.e. supporting responsible business, that values participation in social responsibility activities to reduce their impact on the environment. These practices cover all aspects of the business, including how UPS drives, flies and conduct business worldwide. In terms of its aviation responsibilities, UPS employs fuel analysts to utilise new technologies and continues its objective of reduce emissions in addition to using of environment-friendly transportation practices. 
Where a business culture in which the business strategy is embedded to build a more sustainable corporate brand, that culture needs to permit and ease itself through strategic changes as required. An IBM manager elaborated: "...if a brand adapts itself to market changes and stays at the top of its game for 10 years it means that it is doing well. The IBM brand has been there for 30 years". Having a business culture adaptable to suit changes in customer needs is important for businesses when they enter new foreign markets. By working with a global corporate brand with a business culture that can quickly adapt to changes such as IBM, businesses have the security and trust that they can obtain services suited to their varying needs.

In the context of Ogilvy, the heritage of the company's founder, David Ogilvy as reflected in his famous maxims, has generated a business culture supporting customer orientation and creativity. The creative directors of the company referred to the same maxim of David Ogilvy as being in the centre of their corporate branding: "...if it doesn't sell, it isn't creative". In the initial phases of the company's life cycle, there were some difficulties in implementing this foundational principle. The growth on the scale experienced by Ogilvy in the period up to 1975 resulted in adverse effects. Creativity was stifled due to bureaucratic hindrances, and Ogilvy became conservative in its campaigns in a bid to boost shareholder value and minimise risks. To circumvent this problem, a new stream of creativity was injected into Ogilvy through the formation of semi-autonomous subsidiaries. Also, Ogilvy has achieved to develop a business culture supporting creativity by way of cross-functional integration of interdisciplinary teams composed of several divisions to write some of its most creative brand cases and the 360 Degree Brand Stewardship philosophy acting as the common denominator connecting these teams.

\section{Strength of Brand Relationships to Corporate Brand}

This study supports the building of a corporate brand for business markets depending upon the strength of relationships it has with its internal and external stakeholders. The strength of relationships with internal stakeholders i.e. employees has been giving some valuable messages to the external stakeholders. These relationships have been driven by the business culture of the case study companies (e.g. supporting trust-building, learning and development) and have been significant in building a corporate brand. In this sense, a manager of UPS has explained how the strength of relationships with internal stakeholders affects their corporate branding efforts,

"... We can think about our corporate brand identity internally and externally. How 
good are we in terms of internal and external dynamics? We would like to protect the social rights of our employees which is a significant factor in the construction of the corporate brand identity by our employees. We want to create a sense of belonging for our employees; we try to find out whether working at UPS makes our employees feel good, whether they think they will have professional development and equal opportunities in here. These are the key issues forming our corporate brand identity... If your employees have a sense of belonging to your organization, it means that you have achieved a great deal in terms of your corporate branding... Nowadays your employees can easily comment about their place of employment on social media. Having a good reference from internal stakeholders is very important in building a strong corporate brand".

The strength of B2B relationships with external stakeholders also has a significant role in building a corporate brand. The relationships predominantly with customers are driven by the business culture of the case study companies (e.g. customer-orientation culture, the culture of trust). A creative director from Ogilvy indicated that the strength of B2B relationships with customers and their approach to these relationships help them to differentiate the Ogilvy brand: "For us, the client and creative team relationship has the utmost importance in communicating our brand... We do not say 'no' to the client but instead find a solution for their requests. This approach distinguishes our brand from the others". Another director of the company stated that their approach to developing business relationships with different types of customers is grounded in the unique maxims of the Ogilvy's founder, which are strongly associated with their brand: "... David Ogilvy established this agency. Thus the basis of Ogilvy was based on his maxims. Everything we do is compared with his maxims, whether what we do is aligned with his maxims. When we go for a pitch to a client, we show the core of Ogilvy using these maxims... there is a branding guideline coming from the top on how we talk, how we speak, how we act with the clients... we define our brand differently to different people, to some, we say we are innovative and different. For instance, if our customer is a government, we say 'we understand how you think', 'how the government works'... we never say 'no' to customers. Rather than saying 'no', we try to find solutions to their requests. This approach helps us to strengthen our relationships with the clients and form positive impressions about our brand". A manager from UPS also stated that the approach to form strong relationships with customers influences the positioning of UPS as a trustworthy and reliable brand: 
"We give promises about the things that we can do; we don't give any promises for anything that we can't do... We would find alternative solutions for the things that we can't do... We have a culture of 'yes'. For instance, this strategy has been very prominent since David Abney took the lead. This strategy implies that if a customer approaches us with a request which is not within the portfolio of our solutions, rather than saying them 'no' and explain why their request can't be implemented, we say 'yes' and explain how it may happen...".

External stakeholders can be classified as 'primary' and 'secondary' stakeholders. While primary stakeholders can directly affect the survival of an organization e.g. suppliers and customers, the secondary stakeholders e.g. the media, NGOs etc are less critical for a firm's economic operations. They can mostly influence the firm through its primary stakeholders (Clarkson, 1995; Miles, 2017; Mitchell et al., 1997; Sharma \& Henriques, 2005). Importantly, the interviews revealed that secondary stakeholders could indeed affect how a corporate brand is perceived by its primary stakeholders who are directly connected to the brand. CSR activities, engagements with local authorities and the brand's appearances on the media including social media, have been significant in forming and maintaining relationships with the directly connected stakeholders.

\section{Corporate Personality and Corporate Identity Reinforcing the Corporate Brand}

The building of a corporate brand for business markets depends upon the personality of the corporate. Corporate identity has also been important in building a corporate brand. For example, in the UPS case, the visual elements of the brand's identity have influenced how the corporate brand is seen. UPS has changed its logos four times since it was founded in 1907. Through the years, the UPS logo has developed in a way to reflect the evolving brand identity of the company. UPS's original logo presented an eagle carrying a package with the words 'safe, swift, sure'. All are characterizing what UPS stood for. The third logo was the most recognizable of all the logos and described UPS in the $20^{\text {th }}$ century. The most visible change from this logo to today is the removal of the bow-tied package above the UPS shield. This removal symbolizes UPS's expansion from package delivery into a broader range of supply chain services. Some of its supply chain capabilities include freight services via ground, air, rail as well as the ocean. The package above the shield restrained the brand of showing these new services, by focusing primarily on its package delivery services. It is worth saying that UPS's employees still refer to the brand's logo as 'the shield'. The shield gives customers the 
feeling of assurance and safety and that their goods are handled with care as illustrated by one of the managers: "Our logo has a background in brown colour which symbolizes trust".

Also, the findings illustrate that building a corporate brand for business markets depends upon the perceived personality of the corporate organisation. In one of his famous maxims, David Ogilvy stated that "You now have to decide what 'image' you want for your brand. Image means personality. Products, like people, have personalities, and they can make or break them in the market place" (Ogilvy, 1983). Ogilvy has a unique personality which has formed the core of the brand's identity, being intrinsic to the company and used as the framework for communicating and reflecting the corporate brand. Brand personality explains why people like some brands more than others, even when there is no physical difference between them (Aaker, 1991). Thus, while physical or visual attributes such as a brand's cultural artefacts e.g. logo are related to its identity, the emotional appeal of the brand is related to its personality. Ogilvy is a leader in the advertising field; it has carried out advertising for IBM and UPS brands (Ogilvy and Mather, 2019). At the core of Ogilvy's corporate brand is the underlying notion that 'Good branding is about stirring emotions. It sits in people's minds and has an attachment to the heart' (Ogilvy.com, 2005). This requires a creative flair to cultivate and embed emotive connections in the minds of an increasingly demanding cohort of consumers. Ogilvy's brand identity is built through these emotional associations about David Ogilvy's unique persona.

\section{Product Brand and Corporate Brand}

The outcomes suggest that building of a corporate brand for business markets depend upon products offered by the corporate. The corporate branding of the case study companies has been built by their offerings to customers, including their products, services, processes, technologies, solutions and cultural artefacts. The unique selling propositions of the offerings help to distinguish different corporate brands. A manager from IBM explained that their 'innovative' products and technologies have differentiated their corporate brand, and add,

"...we deliver more patent to the industry than any other company; lots of innovations have been invented in our laboratories such as credit card machines to cash machines... they are all remembered as IBM branded technologies". Similarly, Ogilvy's corporate branding has been associated with their unique focus on embedding creativity into their work: "We are a very creative agency. We provide the most creative idea to the most irrational client. You can win a client 
somehow if you believe in your idea and if the client sees it... This (creativity) is the key differentiator of our brand".

In UPS, the strength of their corporate brand originates from their company's value proposition in terms of creating trust, investing in technology and innovation, and meeting the market needs through their product and service provision,

"...to be able to produce fast and proactive (product and service) solutions for our customers comprise the main dynamics of our corporate branding... the trust that we provide to our customers via our services is the key differentiator of our brand... We ensure that we deliver sustainable services (i.e. sustainable quality, performance), even in peak times. Our customers know that UPS will deliver their consignments at the promised time and see UPS as a trustworthy brand". (Marketing Manager, UPS)

\section{Corporate Brand and Brand Value}

There is support in the literature review that a corporate brand offers tangible and intangible benefits as brand value to its customers in business markets. Where inconsistencies are arising from the misalignments among certain corporate branding constituents, this will prevent the visibility of both intangible and tangible brand value benefits for customer segments. Therefore, when corporate branding is implemented consistently, it has intangible and tangible brand value benefits as universally evident for customers.

The analyses of the interviews for the paper illustrates that when corporate branding strategy is consistently implemented in the three cases, it generates two types of brand value benefits; tangible and intangible. The tangible brand value benefits are identified as the brand's competence (i.e. operational capability), assurance (e.g. assured code of conduct, guarantees) and economic (i.e. market share, profitability) benefits. These benefits are identified as tangible as they are related to the functional valuations of a corporate brand. The intangible brand value benefits of corporate branding have been identified as the brand recognition, brand name, brand image and reputation, brand recall, brand associations and brand transferability. These benefits are labelled as intangible because they are not directly related to the functional valuations of a corporate brand, but are associated with the emotional value attained by the customer in using the corporate brand. 
A manager elaborated that IBM's brand had been seen differently by a younger customer segment due to inconsistencies between the brand's identity and its relationships with diverse customer segments. For example, despite the 'innovative' identity of the brand, younger business segments often perceive IBM as an 'old' brand which is preventing them from understanding its tangible brand value benefits such as service performance, reducing their involvement with the brand as elaborated by one of the managers from IBM,

"IBM's personality is about fun, design, elegance, new, retro... but I think it is seen too archaic, too certain, blue suits to millennium guys i.e. business owners, managing directors etc... When I speak with the managing directors of businesses who are in their 40s and 50s, they see IBM as innovation, quality, assurance, never fails... It is a different brand identity for different people... We do not market ourselves well enough...the interactions with certain customers i.e. millennium guys through social media, are very limited... We need to overcome the issue with the millennium guys that are coming through so that they do not turn on us when they become senior managing directors of businesses".

The other manager from IBM also indicated that for younger customer segments IBM's 'innovation' culture and its logo, as its leading cultural artefact, produce an inconsistent brand image as a business consulting firm,

"Whether it needs to change for the future as we are turning into a very different company; maybe it is a good idea to change that iconic looking eight-bar logo now".

UPS, on the other hand, achieved its tangible brand value benefits by providing consistent corporate branding, which included the delivery of services that are aligned with their brand's business culture. This was partially attributed to fewer variabilities in logistics services, solutions and improving customer relationships in the logistics industry compared to the other case study companies. Consequently, the corporate branding of UPS provided the same tangible brand value benefits such as brand assurance benefits for customer segments with different requirements, as elaborated by one of the managers, 
"Our core corporate culture is the same for all markets such as building trust, investing in technology or innovation, investing in people etc. Such a core mission and vision are applied in every region... Our core business value is trust, and we are the only logistics firm which gives a $100 \%$ money-back guarantee for the express services... While SMEs value our ability to lower the prices, larger businesses may pay premium prices and are after the operational excellence and value-added services... For SMEs delivering a consignment at a specific time may not be too important, but for larger firms, it is often essential. However, all our clients tell us that our brand gives them trust, and they know that their consignment will be delivered without any problems with their receivers".

\section{Brand Value in Relationship Initiation and Management}

This study uncovered brand value from tangible and intangible benefits offered by a corporate brand that initiated relationships with customers in business markets. In terms of brand name and reputation, the 'house of brands' strategy, which uses individual brand names and are not linked to corporate identification. Thus, such strategy can be beneficial in creating distinctly positioned brands in that each brand generates its brand equity and reputation, thus precluding both potential negative associations with the corporate name and cannibalisation (Rao et al., 2004). The 'branded house' strategy, on the other hand, enables a firm to reap the benefits afforded by the corporate brand strategy, although it includes higher risks for the corporate brand. It is easier to increase the recognition of the corporate brand using the 'branded house' strategy. For example, for UPS, this strategy has been highly influential in increasing its recognition and reputation on its advanced capability and assurance of providing fast, reliable and distinguished logistics and supply chain management services and solutions over the years. A manager of UPS stated that their tangible brand value of providing competence to support their customers in reaching market growth and profitability is associated with their brand's intangible value of brand reputation,

"We provide our customers e.g. producers, with services that have sustainable quality which help them to increase their market share and profitability... We have a solutions team which analyses the whole logistical process: where your production takes place; where your warehouses are; how your supply chains work; how your stock orders work; and where your end-users are. So it analyses the processes beginning with production and ending with delivery to the end- 
users".

The 'mixed branding' strategy allows the firm to reap the benefits afforded by the corporate brand strategy and the possibility to create subsidiary names in the brand portfolio. Ogilvy's reputable brand name as an intangible benefit of its corporate branding is associated with certain tangible brand value benefits such as assurances on the service quality and the capability of the brand in producing creative works. These benefits, in turn, have been contributing to the initiation of relationships with the parent and its subsidiary brands as elaborated by one of the creative directors,

"One of the greatest advantages of corporate branding for Ogilvy is the recognition of the brand, respect towards the brand and reputation of the brand. People think how bad this brand can be i.e. capability. They know that if they pay to Ogilvy, they won't have any trouble at the end".

However, it was observed that in some instances the tangible, functional brand value benefits delivered through Ogilvy's regional offices and its subsidiary brands do not match the expected value from the parent brand mainly due to the highly variable and personalized nature of the creative industry offerings. When these mismatches occur, the customer relationship management becomes problematic as elaborated by the other creative director,

"TBWA is famous for its Paris office but not very good in Moscow. These are assessed based on the clients' projects and project awards. The employee and managers are different. Thus, it can be expected that their skills and performances would be different. For instance, if a client is satisfied with the service it receives from a region, it would decide to work with our company in another region. But if it becomes dissatisfied with the service, the client would quit working with Ogilvy".

As another intangible brand value benefit of corporate branding, brand recall provides a brand with the advantage of being involved in the evoked set of customers. It is about what brand comes as the top of a person's mind when a given product category is mentioned. A manager from IBM explained how their capability to provide superior products and services, as a tangible brand value benefit, improves the intangible brand value benefit of their brand's recall in attracting new customers, 
"When we work with the clients, we show our competency to provide certain solutions with good performances. We also supply hardware components which can go along with these solutions. Our clients, in turn, recommend their end-users to purchase the hardware components from IBM. Thus, business clients may help increasing IBM brand's recall for certain hardware components among the end-user groups, that may eventually start working with us".

Similarly, one of the Ogilvy's directors explained how Ogilvy's capability in dealing with large scale operations enhances the brand's recall, and in turn, creates the potential for new relationships,

"Since Ogilvy brand is able to produce a greater amount of work(i.e. competence compared to some other smaller agencies when a customer wishes to meet with the biggest five agencies in its region, Ogilvy would be considered among one of them".

Brand value associations are seen to gain additional leverage as a competitive mechanism in attracting new customers (Michell et al, 2001). Association with a brand which enjoys an admirable reputation would enhance a firm's own reputation; in fact, this is true for any association with reputable brands (Jawoski, 1986). For instance, an IBM's manager explained that in B2B relationships the company sell its products or technology to their business customers or partners, who then use its technology to create and deliver a service for their endusers. The respondent stated that 95 per cent of his business customers believed that associating their services with the power of IBM's branding e.g. using IBM's logo and partner badges and in the use of the IMB PartnerWorld programme agreement, gives a collective real asset and strength. In particular, the assurance provided by the IBM brand motivates their customers to associate their brands with IBM,

"Our business clients believe that having a partnership with the IBM brand gives some assurance to their end-users about the quality of their services. For example, start-ups who do not have sufficient experience of working in the market have the opportunity to get 107 years of assurance from a 100 billion USD worth IBM helping them to get to the doors of their customers". 
A similar comment was provided by one of the managers of UPS,

"Our clients think that working with UPS, using UPS as a solutions provider is a privilege. The clients want to send the message to their end clients that they work with a trustworthy, established, large-sized and quality brand like UPS. Sometimes some firms want to use our brand image, want to put our brand logo on their websites... They gain certain benefits from our brand since UPS provide a certain brand value. Imagine that there is an online start-up company and as an end customer, you will consider starting shopping from their website. When you see the UPS brand as the package delivery company, you would think that this online firm works with UPS, it shouldn't be a problem to make payments to their website. The end customers may develop a perception that if this online retailer works with UPS, they want to operate a quality business or they give importance to this business, or as they are using UPS's logo, they should be reliable. They would think that UPS would not let every firm use it's brand's logo".

The mismatches between the tangible and intangible brand value benefits, on the other hand, may create problems for the initiation and management of B2B relationships with customers. The interviews showed that in creative industries, it is very common that certain reputable brands may use somebody else's creative idea to apply for prestigious awards which constitute a practice acting against their assured code of conduct. When these practices are unearthed and publicized, business customers would tend to disassociate their companies with these brands by not initiating or maintaining B2B relationships. Thus, the manager of UPS stated that they might prefer to disassociate their brand with certain business customers. If such disassociation does not take place, their corporate branding may no longer produce certain tangible (e.g. brand's assured code of conduct) and intangible (e.g. brand's reputation) brand value benefits and may lead the reputable business customers to disassociate their brand with UPS,

"If there is a business activity which contradicts with the values, culture, rules and procedures of UPS, in the first instance, our firm would be very reluctant to initiate that business activity. I do not think that we will start a partnership with an business customer that will not meet our values or culture. For example, in certain regions, there are some firms which send counterfeit products. We would not want to associate our brand with these firms. It is not our duty to check whether the 
consignment includes counterfeit products or not. We collect the consignment, deliver it, the shipment maybe stuck in customs and we may need to deal with the penalty procedures. We do not want to deal with these types of procedures and businesses. There are several companies which are known to sell counterfeit iPhones. We may have financial gains by working with these companies, but we prefer not to work with them. This is because these firms do not align with our corporate values, culture and brand. We do not want our brand to be associated with these businesses and hear that a product which was delivered by UPS was a counterfeit although we are not the marketer or seller of the product".

A brand name is an entity and can be easily transferred from one product or service to another. When it is transferred, it carries some of its attributes with it. Though the same brand can be used for different products, the corporation must be careful of not 'overstretching' it. The brand transferability benefit was evident in the IBM case, known as the producer of personal computers before it sold this business to Lenovo in 2005. More than a decade later, the company has been focusing on its business consulting operations, where it receives a higherrate of return. Some believe that without the personal computer business, IBM was able to return to its core brand, which is business consultancy. The popularity and experience of IBM as a producer of quality personal computers in the past has not hurt its current corporate brand. A manager of IBM indicated that a corporate brand could not be created overnight as brand names require years to achieve respect and trust as IBM". The other manager stated that the competency to adapt itself into different business areas over time has helped to improve the transferability of IBM brand from being a personal computer producer to a business consulting firm and enabled its competency to offer new services and attract new customers,

"The transferability of the IBM brand has been successful, considering where the company came from. IBM was originally set up to make clocks. They then started making punch cards. Through the1930s and 1940s, that was what they used to do. Then it was typewriters and then computers only came in the late 1950s and 1960s when the mainframe started becoming the de facto for big organizations. I think you have a business which has been able to adapt to its time. There wasn't any computer or software 70-80 years ago, so it has been able to adapt and progress in the marketplace. So now we are in the era of cloud computing although it still computes a lot of it is a services market and in the early 1990s, CEO Louis Gerstner 
changed the business from a hardware product company to a services company. Today we are a services company providing cloud services; most of the businessto-business is about cloud computing. IBM has been able to adapt to the changing marketplace and be able to become a different business 10 years later".

\section{$<<$ Insert Table 2 Here $\gg>$}

\section{Discussion}

\section{Theoretical Implications}

The current commentary builds on the growing body of research about the subject of corporate branding in $\mathrm{B} 2 \mathrm{~B}$. The findings from this study generated a conceptual model demonstrating the main constituents of a corporate brand in a B2B context and the subsequent implications of a corporate brand strategy on tangible and intangible brand value benefits and relationships with business customers. In particular, the findings demonstrate that in the context of B2B marketing, the building of a corporate brand's constituents includes the corporate's business culture, relationships with internal and external stakeholders, products, identity and personality. Although previous studies e.g. Harris and Chernatory (2001); Hatch and Schultz, (2001); Knox and Bickerton (2003); and Schultz and Hatch (2003) have mentioned these as key constituents of a corporate brand, they have not identified how these constituents work in B2B settings. This was a research gap addressed by this study.

Our study contributes to the research on corporate branding in a B2B context by reviewing different typologies of brand value for a corporate brand (Balmer and Gray, 2002) as tangible and intangible benefits. In this way, we make a contribution to the current body of knowledge about the development of a brand for B2B customers beyond product brands to the corporate level and contributed to the limited number of studies examining brand value in a B2B context e.g. Vallaster and Lindgreen, 2011. Our study explains how several tangible and intangible values of a corporate brand can provide to business customers. The tangible brand values are identified as the brand's competence i.e. operational capability, assurance e.g. assured code of conduct with guarantees and economic i.e. market share and profitability benefits (Glynn et al. 2010). On the other hand, the intangible brand values are explained in terms of evaluations of a corporate brand's recognition, name, image, reputation, recall, associations and transferability benefits. In previous studies, more emphasis has been given to communicate the functional benefits of a brand in B2B relationships but with scant research attention on 
intangible or emotional aspects (Candi and Kahn, 2016; Mudambi, 2002). This study build on these limited studies by focusing on both functional or tangible and emotional or intangible aspects of a corporate brand's value.

More importantly, our study shows that in a B2B context, all these benefits are generated through a diverse range of constituents brought together for the formation of a corporate brand. The higher the consistency of these constituents, the stronger will be the ability of the corporate brand to communicate the value benefits it offers. In this sense, this study builds on the previous studies (e.g. Knox and Bickerton, 2003; Schultz and Hatch, 2003) by showing that besides the availability of the constituents shaping a corporate brand, the consistencies among these constituents affect how the corporate brand will be perceived or valued by customers and other stakeholders. Our study also makes a contribution to the literature on marketing communications that discusses product branding (Candi and Kahn, 2016; Leek and Christodoulides, 2012; Perrson, 2010) by demonstrating that a corporate brand enables customised value generation for B2B customers in its relationship with corporate brands e.g. the approach to communicate with diverse customer segments. These findings are based on the similarities identified in the three cases that sustain the success of their corporate brands using the tangible and intangible brand value benefits offered by their firms to their customers.

Our study also shows that the brand value benefit of a corporate brand eventually supports both the initiation and management of the relationships with business customers. This was a contribution to the literature on corporate branding as a limited number of previous research studies examined the role of corporate branding in enhancing brand loyalty from an business customer's viewpoint, which is related to the maintenance rather than initiation of business-tobusiness (B2B) relationships (Ryan and Silvanto, 2013). An exploration of the role of corporate brand value in both relationship initiation and relationship maintenance from the perspective of suppliers has provided not only understanding about the potential issues influencing the perceptions of customers, but also the problems experienced by suppliers in this process.

Our findings show that when corporate branding does not enable a supplier to attain a reputable corporate brand, the value of engaging in a B2B relationship with that supplier reduces for customers. In this sense, we contribute to the previous discussions on B2B product brands (e.g. Mudambi, 2002; Leek and Christodoulides, 2012) by showing that in corporate branding context, intangible value benefits of a supplier's corporate brand affect B2B relationships with 
business customers. More specifically, business customers would tend to initiate relationships and associate with a supplier, if the supplier's corporate brand brings them some intangible value benefits such as image and reputation and tangible value benefits such as assured performance benefits. In contrast to a B2C context, suppliers would be more cautious of how image and reputation of business customers might influence the outlook of their corporate brand in initiating and managing relationships with their customers. From a supplier's perspective, in creative industries such as Ogilvy's advertising industry, it was shown that several issues were affecting the reputation and image of the corporate brand such as the difficulties to control competence of diverse subsidiaries in different regions.

While our findings are consistent with the product branding research undertaken in B2B marketing contexts, it is also one of the initial studies that have explored internal aspect or antecedents of building a corporate brand for B2B customers. In particular, we extend the boundary of knowledge about the corporate brand from product branding to corporate branding to consider economic benefits with assurances and evaluations offered by a corporate brand to consumers in competitive market researches (Mudambi, 2002; Leek and Christodoulides, 2012). However, this study adds to the previous studies emphasizing the benefits of branding in taking advantage of charging premium prices (Gupta et al., 2014) by revealing that this depends on the size and resources of the business owned by a business customer in the B2B context. In certain instances, the size and resources of the business customer may prevent them from paying premium prices for a reputable corporate brand.

\section{Managerial Implications}

This study has considered the main constituents of a corporate brand in the B2B context. It has presented tangible and intangible corporate brand values for the business customer and further, how the three case organisations in their corporate brand identities have represented their brand values to underpin or advance their relationship initiation and maintenance with business customers.

Managers must consider corporate brand values and their implications for influencing business relationship management and brand performance outcomes. In particular, managers should evaluate their company's brand through its business culture identity, personality, products, and relationships with internal and external stakeholders as its constituents. This necessitates effective coordination for ensuring collective success of the implementation of the company 
corporate brand strategy. Managers need to identify the values or benefits of each of these brand constituents and work with staff to communicate these benefits to customers. Thus, it is important to ensure that all these constituents are consistently communicated to different stakeholders, including the business customers to strengthen the corporate brand. Communication of these constituents requires the engagement of employees as internal stakeholders of the brand. The human resources department can play an important role in aligning employees knowledge of the company with the company corporate brand philosophy. For example, in the case of IBM, the corporate brand constituents included the identity, personality and products, which when offered were perceived differently by diverse market segments such as mature senior directors and millennial executives. This requires IBM marketing communications to align its corporate brand values according to a segment's perceived benefits in the process of business relationship development.

Business customers are concerned about how corporate branding of their suppliers may affect their positioning and performance in the market. In this sense, if companies were to achieve consistency in corporate branding, they would be likely to create superior customer value. Companies operating in $\mathrm{B} 2 \mathrm{~B}$ markets can train their employees about how they should communicate the identities and personalities of their corporate brands to their business customers. Managers need to ensure that staff from different functions within a company should have the same understanding of a corporate brand's identity and personality, and work collaboratively to develop and deliver consistent marketing communications messages and outputs to support the corporate brand. This is important as different functional departments may have varying levels of awareness about the identity and personality of a corporate brand which in turn can diminish its effective communication.

A corporate brand confers intangible value such as it creates demand for the company's products and services. It also provides tangible value in terms of capability or positioning to demand premium pricing based on a superior customer value. This facilitates early stages of relationship development with business customers. Importantly, suppliers need to ensure that they deliver not only tangible value benefits to their customers associated with the functional evaluation of their corporate brands, but also intangible value benefits related to the emotional value attained by the customer in using the corporate brand. Managers need to ensure that they identify different needs of the diverse market segments in providing them with various types of value benefits in a way that is consistent with their corporate brand. For example, start-up 
companies may be more interested in gaining reputational benefits from a supplier's corporate brand in order to increase their market recognition. Small businesses may seek whether a supplier's corporate brand promises economic benefits, which they consider as tangible benefits. In contrast, an established business customer may be interested in finding out whether a supplier's corporate brand promises both operational competence and reputational benefits. Although suppliers need to communicate their corporate brands in a consistent manner, they need to be selective that product-related benefits can be important for certain business relationship constituents such as how the suppliers treat their internal stakeholders may influence other market segments. The implication for management is to train their staff about how to identify and explore effective corporate brand-related expectations of their business customers belonging to different market segments.

\section{Limitations and future research}

The main limitations related to the methodology are concerned with sampling and generalisability though the present study provided insights through three global firms that have used each other's services. Future research could explore other industry sectors and environmental settings, e.g., manufacturing, competitive high-technology industries, tourism and fashion. This may include less well known and reputable brands to compare their corporate brands with more reputable and well-known brands to analyse such strategies used to initiate and manage relationships with their business customers.

This study examined the internal side of the corporate branding strategy of successful global businesses with visible corporate brand communications. Future research could compare different cases which have been successful and unsuccessful in their corporate branding strategies to uncover what had led a corporate branding strategy to failure. As shown in this study, global businesses would benefit from managing business relationships with their internal and external stakeholders as a means to enhance as well as protect their corporate brands from any business fallouts. Finally, this study recommends the future researchers to testing the model quantitatively. 


\section{References}

Aaker, D. (1991), Managing Brand Equity. Capitalizing on the Value of a Brand Name. Free Press, New York.

Abratt, R. (1989), "A new approach to the corporate image management process", Journal of Marketing Management, Vol. 5, No. 1, pp. 63-76.

Accessed 08/03/2019: http://dx.doi.org/10.5465/amd.2013.0020

Anees-ur-Rehman, M., Saraniemi, S., Ulkuniemi, P. and Hurmelinna-laukkanen, P. (2017), "The strategic hybrid orientation and brand performance of B2B SMEs", Journal of Small Business and Enterprise Development, in press.

Aspara, J. and Tikkanen, H. (2008), "Adoption of corporate branding by managers: Case of a Nordic business-to-business company”, Journal of Brand Management, Vol. 16, No. 12, pp. 80-91.

B2B Marketing (2017), Top 20 most valuable B2B brands revealed, B2B marketing, available at https://www.b2bmarketing.net/en-gb/resources/news/top-20-most-valuable-b2bbrands-revealed.

Backhaus, K. and Tikoo, S. (2004), “Conceptualizing and researching employer branding”, Career Development International, Vol. 9, No. 5, pp. 501-517.

Ballantyne, D. and Aitken, R. (2007), "Branding in B2B markets: Insights from the service dominant logic of marketing”, Journal of Business \& Industrial Marketing, Vol. 22, No. 6, pp. 363-371.

Balmer, J. M. (1995), "Corporate branding and connoisseurship", Journal of General Management, Vol. 21, No. 1, pp. 24-46.

Balmer, J. M. (1998), "Corporate identity and the advent of corporate marketing", Journal of Marketing Management, Vol. 14, No. 8, pp. 963-996.

Balmer, J. M. (2001), “Corporate identity, corporate branding and corporate marketing-seeing through the fog", European Journal of Marketing, Vol. 35, No. 3/4, pp. 248-291.

Balmer, J. M. (2014), “Wally Olins (1930-2014), Corporate identity ascendancy and corporate brand hegemony. Celebrating the life of Wally Olins: Leading corporate identity exponent and prominent brand proponent", Journal of Brand Management, Vol. 21, No. 6, pp. 459-468.

Balmer, J. M. and Gray, E. R. (2003), “Corporate brands: what are they? What of them?”, European Journal of Marketing, Vol. 37, No. 7/8, pp. 972-997. 
Balmer, J. M. and Greyser, S. A. (2003), Revealing the corporation: perspectives on identity, image, reputation, corporate branding, and corporate-level marketing: an anthology, Psychology Press, UK.

Balmer, J. M. and Soenen, G. B. (1999), "The acid test of corporate identity management ${ }^{\mathrm{TM} \text { ", }}$ Journal of Marketing Management, Vol. 15, No. 1-3, pp. 69-92.

Balmer, J. M. and Wilson, A. (1998), "Corporate identity: there is more to it than meets the eye", International Studies of Management \& Organization, Vol. 28, No. 3, pp. 12-31.

Balmer, J.M.T. (2005), “Corporate brand cultures and communities”, in: J.E. Schroeder and M. Salzer-Morling (eds.) Brand Culture. London and New York: Routledge, pp. 34-49.

Balmer, J.M.T. (2013), “Corporate brand orientation: What is it? What of it?” Journal of Brand Management, Vol. 20, No. 9, pp. 723-741

Balmer, J.M.T. and Greyser, S.A. (2002), "Managing the multiple identities of the corporation", California Management Review, Vol. 44 No. 3, pp. 72-86.

Balmer, J.M.T., Brexendorf, T.O., \& Kernstock, J. (2013), “Corporate brand management - A leadership perspective”, Journal of Brand Management, Vol. 20, No. 9, pp. 717-722.

Baumgarth, C. and Schmidt, M. (2010), "How strong is the business-to-business brand in the workforce? An empirically-tested model of 'internal brand equity' in a business-tobusiness setting”, Industrial Marketing Management, Vol. 39, No. 8, pp. 1250-1260.

Beltrone, G. (2015), "UPS is about way more than just shipping boxes in its heady new global push", Adweek, available at: http://www.adweek.com/creativity/ups-about-way-morejust-shipping-boxes-its-heady-new-global-push-163560/

Bendapudi, N. and Leone, R. P. (2002), "Managing business-to-business customer relationships following key contact employee turnover in a vendor firm", Journal of Marketing, Vol. 66, No. 2, pp. 83-101.

Berens, G., Riel, C. B. V. and Bruggen, G. H. V. (2005), "Corporate associations and consumer product responses: The moderating role of corporate brand dominance", Journal of Marketing, Vol. 69, No. 3, pp. 35-48.

Berry, L. L. (2000), "Cultivating service brand equity”, Journal of the Academy of Marketing Science, Vol. 28, No. 1, pp. 128-137.

Berthon, P., Pitt, L., Parent, M. and Berthon, J. P. (2009). “Aesthetics and ephemerality: observing and preserving the luxury brand". California Management Review, Vol. 52, No. 1, pp. 45-66.

Beverland, M., Napoli, J., and Lindgreen, A. (2007). Industrial global brand leadership: A capabilities view. Industrial marketing management, Vol. 36, No. 8, pp. 1082-1093. 
Bhattacharya, C. B. and Sen, S. (2003), "Consumer-Company Identification: A Framework for Understanding Consumers' Relationships with Companies”, Journal of Marketing, Vol. 67, No. 2, pp. 76-88.

Brito, C.M. (1999). Issue-based nets: a methodological approach to the sampling issue in industrial networks research. Qualitative Market Research, Vol. 2, No. 2, pp. 92-102.

Bromley, D. B. (2001), "Relationships between personal and corporate reputation", European Journal of Marketing, Vol. 35, No. 3/4, pp. 316-334.

Brown, B. P., Bellenger, D. N. and Johnston, W. J. (2007), “The implications of business-tobusiness and consumer market differences for B2B branding strategy", Journal of Business Market Management, Vol. 1, No. 3, pp. 209-230.

Burmann, C. and Zeplin, S. (2005), "Building brand commitment: A behavioural approach to internal brand management", Journal of Brand Management, Vol. 12, No. 4, pp.279-300.

Burmann, C., Jost-Benz, M. and Riley, N. (2009), "Towards an identity-based brand equity model", Journal of Business Research, Vol. 62, No. 3, pp. 390-397.

Candi, M. and Kahn, K. B. (2016), "Functional, emotional, and social benefits of new B2B services", Industrial Marketing Management, Vol. 57, August, pp. 177-184.

Čater, T. and Čater, B. (2010), "Product and relationship quality influence on customer commitment and loyalty in B2B manufacturing relationships", Industrial Marketing Management, Vol. 39, No. 8, pp. 1321-1333.

Chen, Z., Huang, Y. and Sternquist, B. (2011), "Guanxi practice and Chinese buyer-supplier relationships: The buyer's perspective", Industrial Marketing Management, Vol. 40, pp. $569-580$.

Cornelissen, J. and Harris, P. (2001), “The corporate identity metaphor: perspectives, problems and prospects", Journal of Marketing Management, Vol. 17, No. 1-2, pp. 49-71.

Creswell, J.W. (2014), Research design: qualitative and mixed method approaches, $4^{\text {th }}$

Cretu, A. E. and Brodie, R. J. (2007), "The influence of brand image and company reputation where manufacturers market to small firms: A customer value perspective", Industrial Marketing Management, Vol. 36, No. 2, pp. 230-240.

Da Silva, R. V. and Alwi, S. F. S. (2008), “Online brand attributes and online corporate brand images”, European Journal of Marketing, Vol. 42, No. 9/10, pp. 1039-1058.

De Chernatony, L. and Riley, F. D. O. (1999), "Experts' views about defining services brands and the principles of services branding”, Journal of Business Research, Vol. 46, No. 2, pp. 181-192. 
De Chernatony, L. and Segal-Horn, S. (2001), "Building on services' characteristics to develop successful services brands", Journal of Marketing Management, Vol. 17, No. 7-8, pp. 645-669.

De Chernatony, L. and Segal-Horn, S. (2003), "The criteria for successful services brands", European Journal of Marketing, Vol. 37, No. 7/8, pp. 1095-1118.

De Roeck, K., Maon, F., and Lejeune, C. (2013). Taking up the challenge of corporate branding: an integrative framework. European Management Review, Vol. 10, No. 3, pp. 137-151.

Dutton, J. E., Dukerich, J. M. and Harquail, C. V. (1994), “Organizational images and member identification”, Administrative Science Quarterly, Vol. 39, No. 2, pp. 239-263. edition, Thousand Oaks: SAGA pub.

Eisenhardt, K. M. (1989), "Building theories from case study research", The Academy of Management Review, Vol. 14 No. 4, pp. 532-550.

Eisenhardt, K. M. and Graebner, M. E. (2007), "Theory building from case studies: Opportunities and challenges", Academy of Management Journal, Vol. 50, No. 1, pp. 25 32.

Ellis, N. and Hopkinson, G. (2010), “The construction of managerial knowledge in business networks: Managers' theories about communication”, Industrial Marketing Management, Vol. 39, No. 3, pp. 413-424.

Elsäßer, M. and Wirtz, B. W. (2017), "Rational and emotional factors of customer satisfaction and brand loyalty in a business-to-business setting", Journal of Business \& Industrial Marketing, Vol. 32, No. 1, pp. 138-152.

Erevelles, S., Stevenson, T. H., Srinivasan, S. and Fukawa, N. (2008), “An analysis of B2B ingredient co-branding relationships", Industrial Marketing Management, Vol. 37, No. 8, pp. 940-952.

Fetscherin, M. and Usunier, J-C. (2012), “Corporate branding: an interdisciplinary literature review", European Journal of Marketing, Vol. 46, No. 5, pp. 733-753.

Foroudi, M. M., Balmer, J. M., Chen, W., Foroudi, P., \& Patsala, P. (2020). Explicating place identity attitudes, place architecture attitudes, and identification triad theory. Journal of Business Research, Vol. 109 (March), pp. 321-336.

Foroudi, P., Cuomo, M. T., Foroudi, M. M., Katsikeas, C. S., and Gupta, S. (2019). Linking identity and heritage with image and a reputation for competition. Journal of Business Research (Just accepted) 
Foroudi, P., Dinnie, K., Kitchen, P. J., Melewar, T. C. and Foroudi, M. M. (2017), "IMC antecedents and the consequences of planned brand identity in higher education", European Journal of Marketing, Vol. 51, No. 3, pp. 528-550.

Foroudi, P., Foroudi, M. M., Nguyen, B., \& Gupta, S. (2019). Conceptualizing and managing corporate logo: a qualitative study. Qualitative Market Research: An International Journal (Just accepted).

Foroudi, P., Jin, Z., Gupta, S., Foroudi, M. M., and Kitchen, P. J. (2018). Perceptional components of brand equity: Configuring the Symmetrical and Asymmetrical Paths to brand loyalty and brand purchase intention. Journal of Business Research, Vol. 89(Aug), pp. 462-474.

Fortune (2019), “James Dyson's electric shock”, November issue. Https://Fortune.com (accessed Oct $\left.17^{\text {th }}\right)$.

Gioia, D. A., Schultz, M. and Corley, K. G. (2000), "Organizational identity, image, and adaptive instability", Academy of Management Review, Vol. 25, No. 1, pp. 63-81.

Glynn, M. S. and Woodside, A. G. (2009), Business-to-business brand management: Theory, research and executive case study exercises. Emerald Group Publishing Limited, Bingley.

Gray, E. R. and Balmer, J. M. (1998), "Managing corporate image and corporate reputation”, Long Range Planning, Vol. 31, No. 5, pp. 695-702.

Gupta, S., Malhotra, N. K., Czinkota, M., \& Foroudi, P. (2016). Marketing innovation: A consequence of competitiveness. Journal of Business Research, Vol 69, No.12, pp. 56715681 .

Gupta, S., Rudd, J. and Lee, N. (2014), "Business sustainability through successful integration of marketing and operations", Industrial Marketing Management, Vol. 43, No.1, pp. 35 .

Gupta, S., Väätänen, J. and Khaneja, S. (2016), "Value added reseller or value at risk: The dark side of relationships with VARs", Industrial Marketing Management, Vol. 55, May, pp. 110-118.

Harris, F. and Chernatory, L. (2001), “Corporate branding and corporate brand performance”, European Journal of Marketing, Vol. 35, No. 3/4, pp. 441-456.

Hatch, M. J. and Schultz, M. (2000), “Are strategic stars aligned for your corporate brand?”, Harvard Business Review, Vol. 79, No. 2, pp. 128-134.

Hatch, M. J. and Schultz, M. (2008), Taking brand initiative: How companies can align strategy, culture, and identity through corporate branding, John Wiley \& Sons, USA. 
Hatch, M. J. and Schultz, M. (2015), "Organizational identity and culture in the context of

He, H. W. and Mukherjee, A. (2009), "Corporate identity and consumer marketing: A process model and research agenda", Journal of Marketing Communications, Vol. 15, No. 1, pp. $1-16$.

Homburg, C., Stierl, M. and Bornemann, T. (2013), "Corporate social responsibility in business-to-business markets: how organizational customers account for supplier corporate social responsibility engagement”, Journal of Marketing, Vol. 77, No. 6, pp. 54-72.

Hur, W. M., Kim, H. and Woo, J. (2013), "How CSR leads to corporate brand equity: Mediating mechanisms of corporate brand credibility and reputation", Journal of Business Ethics, Vol. 125 No. 1, pp. 75-86.

Iglesias, O., Ind, N., \& Alfaro, M. (2013), "The organic view of the brand: a brand value cocreation model”, Journal of Brand Management, Vol. 20, No. 8, pp. 670-688.

Iglesias, O., Landgraf, P., Ind, N., Markovic, S., and Koporcic, N. (2019). Corporate brand identity co-creation in business-to-business contexts. Industrial Marketing Management (Just Accepted).

Ind, N. (1997), “The corporate brand”, in The Corporate Brand (pp. 1-13). Palgrave Macmillan UK.

Ind, N., and Bjerke, R. (2007), Branding governance: a participatory approach to the brand building process, John Wiley \& Sons.

Ind, N., Iglesias, O., and Schultz, M. (2013). Building brands together: Emergence and outcomes of co-creation. California Management Review, Vol. 55, No. 3, pp. 5-26.

Jap, S.D. and Anderson, E. (2007), "Testing a life-cycle theory of cooperative interorganizational relationships: Movement across stages and performance", Management Science, Vol. 53, No. 2, pp. 260-275.

Jo Hatch, M. and Schultz, M. (2003), "Bringing the corporation into corporate branding", European Journal of Marketing, Vol. 37, No. 7/8, pp. 1041-1064.

Johnsen, R. E. and Lacoste, S. (2016), "An exploration of the 'dark side' associations of conflict, power and dependence in customer-supplier relationships", Industrial Marketing Management, Vol. 59, pp. 76-95.

Kapferer, J. N. (2001), (Re) inventing the brand: can top brands survive the new market realities?, Kogan Page Publishers, UK. 
Karmark, E. (2005), "Living the brand. In Towards the Second Wave of Corporate Branding”, in Schultz, M., Antorini, Y.M. and Csaba, F.F. Corporate Branding - Purpose, People, Process. Copenhagen Business School Press, Copenhagen, pp. 103-124.

Kaufmann, H. R., Czinkota, M. R. and Zakrzewski, M. (2015), "B2B and internal relationships and curative international marketing: A polish case study", Industrial Marketing Management, Vol. 51, No. Nov, pp. 69-78.

Kernstock, J. and Brexendorf, T. O. (2009), "Implications of Habermas's "theory of communicative action" for corporate brand management", Corporate Communications: An international journal, Vol. 4, No. 4, pp. 389-403.

Kim, J. H. and Hyun, Y. J. (2011), “A model to investigate the influence of marketing-mix efforts and corporate image on brand equity in the IT software sector", Industrial Marketing Management, Vol. 40, No. 3, pp. 424-438.

Knox, S. and Bickerton, D. (2003), “The six conventions of corporate branding”, European Journal of Marketing, Vol. 37, No. 7/8, pp. 998-1016.

Knudsen, G. H. (2012), “Man's last stand! Polysemy and dialogue in advertising reception', Advertising \& Society Review, Vol. 13, No. 2. Pp. 41-62.

Kotler, P. and Pfoertsch, W. (2006), B2B Brand Management, Springer Science \& Business Media, USA.

Kuhn, K. A., Alpert, F. and Pope, N. K. L. (2008), “An application of Keller's brand equity model in a B2B context", Qualitative Market Research: An International Journal, Vol. 11, No. 1, pp. 1-40.

Lai, C-S., Chiu, C-J., Yang, C-Y. and Pai, D-C. (2010), "The effects of corporate social responsibility on brand performance: The mediating effect of industrial brand equity and corporate reputation”, Journal of Business Ethics, Vol. 95, No. 3, pp. 457-469.

Lambkin, M. C. and Muzellec, L. (2010), "Leveraging brand equity in business-to-business mergers and acquisitions", Industrial Marketing Management, Vol. 39, No. 8, pp. 12341239.

Leek, S. and Christodoulides, G. (2011), A literature review and future agenda for B2B branding: Challenges of branding in a B2B context, Industrial Marketing Management, Vol. 40, No. 6, pp. 830-837.

Lemke, F., Clark, M. and Wilson, H. (2011), “Customer experience quality: an exploration in business and consumer contexts using repertory grid technique", Journal of the Academy of Marketing Science, Vol. 39, No. 6, pp. 846-869. 
Lencioni, P. M. (2002), “Make your values mean something”, Harvard Business Review, Vol. 80, No. 7, pp. 113-117.

Lynch, J. and de Chernatony, L. (2004), “The power of emotion: Brand communication in business-to-business markets", Journal of Brand Management, Vol. 11, No. 5, pp. 403419.

Lyons, D. (2017), "What 'old-school' tech giants are doing to attract young talent", Forbes, available at: http://fortune.com/2017/02/22/corporate-tech-hiring-recruitment/ managed change: transformation in the Carlsberg Group, 2009-2013", Academy of Management Discoveries, Vol. 1, No. 1, pp. 61-92.

Markwick, N. and Fill, C. (1997), “Towards a framework for managing corporate identity”, European Journal of Marketing, Vol. 31, No. 5/6, pp. 396-409.

Mary J. H. and Schultz, M. (2003), "Bringing the corporation into corporate branding", European Journal of Marketing, Vol. 37, No. 7/8, pp. 1041-1064,

Mason C. and Simmons, J. (2014), "Embedding Corporate Social Responsibility in Corporate Governance approach”, Journal of Business Ethics, Vol. 119, No. 1, pp. 77-86.

McDonald, M. H., De Chernatony, L. and Harris, F. (2001), “Corporate marketing and service brands-Moving beyond the fast-moving consumer goods model", European Journal of Marketing, Vol. 35, No. 3/4, pp. 335-352.

Merrilees, B. (2007). A theory of brand-led SME new venture development. Qualitative Market Research: An International Journal, Vol. 10, No. 4, pp. 403-415.

Mitchell, P., King, J., \& Reast, J. (2001), "Brand values related to industrial products", Industrial Marketing Management, Vol. 30, pp. 415-425.

Morhart, F. M., Herzog, W. and Tomczak, T. (2009), "Brand-specific leadership: Turning employees into brand champions", Journal of Marketing, Vol. 73, No. 5, pp. 122-142.

Mudambi, S. (2002). "Branding importance in business-to-business markets: Three buyer clusters”, Industrial Marketing Management, Vol. 31, No. 6, pp. 525-533.

Mudambi, S. (2002). Branding importance in business-to-business markets: Three buyer clusters. Industrial marketing management, Vol. 31, No. 6, pp. 525-533.

Mudambi, S., Doyle, P. and Wong, V. (1997), “An exploration of branding in industrial markets”. Industrial Marketing Management, Vol. 26, No. 5, pp. 433-446.

Nyadzayo, M.W., Matanda, M.J. and Ewing. M.T. (2015), “The impact of franchisor support, brand commitment, brand citizenship behaviour, and franchisee experience on franchisee-perceived brand image", Journal of Business Research, Vol. 68, No.9, pp. 1886- 1894. 
Ogilvy and Mather, (2019), accessed 08/03/2019, IBM: https://ogilvy.co.uk/work-article/ibm). Ogilvy, D. (1983), Ogilvy on advertising, Crown, New York.

Olins, W. (1978), “The corporate personality: An inquiry into the nature of corporate identity”, Design Council, London, UK

Paparoidamis, N. G., Katsikeas, C. S. and Chumpitaz, R. (2017), “The role of supplier performance in building customer trust and loyalty: A cross-country examination", Industrial Marketing Management, in press.

Park, C. W., MacInnis, D. J. and Eisingerich, A. B. (2016), Brand architecture design and brand naming decisions, The Routledge Companion to Contemporary Brand Management, Routledge, London.

Patton, M. Q. (2002), Designing qualitative studies [excerpt: Purposeful sampling]. In Qualitative research and evaluation methods (3rd ed., pp. 230-247), Sage, Thousand Oaks, CA.

Patton, M. Q. (1990), Qualitative Evaluation and Research Methods (2nd ed.), Sage, Newbury Park, CA.

Payne, A. and Frow, P. (2004), The role of multichannel integration in customer relationship management, Industrial Marketing Management, Vol. 33, February, pp. 527-538.

Persson, N. (2010), An exploratory investigation of the elements of B2B brand image and its relationship to price premium, Industrial Marketing Management, Vol. 39, No. 8, pp. 1269-1277.

Peters, C., Amato, C. H. and Hollenbeck, C. R. (2007), "An exploratory investigation of consumers' perceptions of wireless advertising”, Journal of Advertising, Vol. 36, No. 4, pp. 129-145.

Rao, V. R., Agarwal, M. K. and Dahlhoff, D. (2004), "How Is Manifest Branding Strategy Related to the Intangible Value of a Corporation?", Journal of Marketing, Vol. 68, No. 4, pp. 126-141.

Riley, D. F. and de Chernatony, L. (2000). “The service brand as relationships builder”, British Journal of Management, Vol. 11, pp. 137-150.

Roll, M. (2004), Perspectives on corporate branding strategy, Venture Republic.

Ryan, J. and Silvanto, S. (2013), "The critical role of corporate brand equity in B2B marketing: An example and analysis", Marketing Review, Vol. 13, No. 1, pp. 39-50.

Sarkar, S. and Mishra, P. (2017), "Market orientation and customer-based corporate brand equity (CBCBE): a dyadic study of Indian B2B firms", Journal of Strategic Marketing, Vol. 25 No. 5-6, pp. 367-383. 
Schultz, M. and De Chernatony, L. (2002), "Introduction: The challenges of corporate branding", Corporate Reputation Review, Vol. 5 , No. 2/3, pp. 105.

Seddon, J. (2015), "The brand in the boardroom", Journal of Advertising Research, Vol. 55, No. 2, pp. 146-161.

Simoes, C., Dibb, S. and Fisk, R. P. (2005), "Managing corporate identity: an internal perspective", Journal of the Academy of Marketing Science, Vol. 33, No. 2, pp. 153-168.

Simoes, C., Singh, J. and Perin, M. G. (2015), "Corporate brand expressions in business-tobusiness companies' websites: Evidence from Brazil and India", Industrial Marketing Management, Vol. 51, No. Nov, pp. 59-68.

Souiden, N., Kassim, N. M. and Hong, H. J. (2006), “The effect of corporate branding dimensions on consumers' product evaluation: A cross-cultural analysis”, European Journal of Marketing, Vol. 40, No. 7/8, pp. 825-845.

Stein, L. (2017), “Ogilvy names new leaders as disciplines form one 'integrated enterprise'”, AdvertisigAge, available at: http://adage.com/article/agency-news/working-ogilvystructure-leadership/307729/

Suri, H. (2011), "Purposeful sampling in qualitative research synthesis", Qualitative Research Journal, Vol. 11, No. 2, pp. 63-75.

Törmälä, M. and Gyrd-Jones, R. I. (2017), "Development of new B2B venture corporate brand identity: A narrative performance approach", Industrial Marketing Management, in press.

Tourky, M. E., Foroudi, P., Suraksha, G., and Shaalan, A. (2020). Conceptualizing corporate identity in a dynamic environment, Qualitative Market Research: International Journal (Just accepted)

Ulaga, W. and Eggert, A. (2006), "Relationship value and relationship quality: Broadening the nomological network of business-to-business relationships", European Journal of Marketing, Vol. 40, No. 3/4, pp. 311-327.

Urde, M. (2003), "Core value-based corporate brand building", European Journal of Marketing, Vol. 37, No. 7/8, pp. 1017-1040.

Urde, M. (2009), "Uncovering the corporate brand's core values", Management Decision, Vol. 47, No. 4, pp. 616-638.

Urde, M. (2013), “The corporate brand identity matrix”, The Journal of Brand Management, Vol. 20, No. 9, pp. 742-761.

Urde, M., and Greyser, S. A. (2015), "The Nobel Prize: the identity of a corporate heritage brand", Journal of Product and Brand Management, Vol. 24, No. 4, pp. 318-332. 
Vallaster, C. and Lindgreen, A. (2011), Corporate brand strategy formation: Brand actors and the situational context for a business-to-business brand. Industrial Marketing Management, Vol. 40, No. 7, pp. 1133-1143.

Valtakoski, A. (2015), "Initiation of buyer-seller relationships: The impact of intangibility, trust and mitigation strategies", Industrial Marketing Management, Vol. 44, No. Jan, pp. 107-118.

Van Heerden, C. H. and Puth, G. (1995), "Factors that determine the corporate image of South African banking institutions: an exploratory investigation", International Journal of Bank Marketing, Vol. 13, No. 3, pp. 12-17.

Van Riel, A. C., De Mortanges, C. P. and Streukens, S. (2005), "Marketing antecedents of industrial brand equity: An empirical investigation in specialty chemicals", Industrial Marketing Management, Vol. 34, No. 8, pp. 841-847.

Varadarajan, R. (2010), "Strategic marketing and marketing strategy: domain, definition, fundamental issues and foundational premises", Journal of the Academy of Marketing Science, Vol. 38, No. 2, pp. 119-140.

Veloutsu, C. and Moutinho, L. (2009), "Brand relationships through brand reputation and brand tribalism”, Journal of Business Research, Vol. 62, No. 3, pp. 314-322.

Wathne, K. H. and Heide, J. B. (2000), “Opportunism in interfirm relationships: Forms, outcomes and solutions", Journal of Marketing, Vol. 64, No. Oct, pp. 36-51.

Woo, K. S. and Ennew, C. T. (2004), "Business-to-business relationship quality: An IMP interaction-based conceptualization and measurement", European Journal of Marketing, Vol. 38, No. 9/10, pp. 1252-1271.Wright, L.T. and Wright, R. (2016), "Qualitative Research", in Baker, M. and Hart, S., (eds), The Marketing Textbook, Elsevier, 7th edition, 191-210.

Wymer Jr, W. W. and Samu, S. (2003), "Dimensions of business and nonprofit collaborative relationships", Journal of Nonprofit \& Public Sector Marketing, Vol. 11, No. 1, pp. 322.

Yin R. (2014), Case Study Research: Design and Methods, Sage, Los Angeles.

Zou, H. and Ghauri, P. (2010), "Internationalizing by learning: the case of Chinese high-tech new ventures", International Marketing Review, Vol. 27, No. 2, pp. 223-244. 
Table 1: In-depth interviews with managers

\begin{tabular}{|c|c|c|c|c|}
\hline Company & Interview position & $\begin{array}{l}\text { Interview } \\
\text { base }\end{array}$ & $\begin{array}{l}\text { Interview } \\
\text { date }\end{array}$ & $\begin{array}{l}\text { Interview } \\
\text { duration }\end{array}$ \\
\hline \multirow[t]{2}{*}{ IBM } & $\begin{array}{l}\text { Business Development } \\
\text { Manager }\end{array}$ & India & 04.05 .2017 & 60 minutes \\
\hline & Marketing Manager & $\begin{array}{l}\text { United } \\
\text { Kingdom }\end{array}$ & 05.05 .2017 & 120 minutes \\
\hline \multirow{2}{*}{$\begin{array}{l}\text { Ogilvy and } \\
\text { Mather }\end{array}$} & Senior Creative Director & Turkey & 17.04 .2017 & 60 minutes \\
\hline & Senior Creative Director & $\begin{array}{l}\text { United Arab } \\
\text { Emirates }\end{array}$ & 19.04 .2017 & 120 minutes \\
\hline \multirow[t]{2}{*}{ UPS } & Marketing Manager & Turkey & 22.05 .2017 & 90 minutes \\
\hline & $\begin{array}{l}\text { Business Development } \\
\text { Manager }\end{array}$ & Germany & 15.06 .2017 & 120 minutes \\
\hline \multicolumn{5}{|l|}{$\begin{array}{l}\text { Topics } \\
\text { discussed: }\end{array}$} \\
\hline \multicolumn{5}{|c|}{$\begin{array}{l}\text { The understanding of the concept of corporate brand in a B2B context. } \\
\text { The main factors influencing the corporate brand in a B2B context. } \\
\text { The main tangible and intangible brand values in a B2B context. } \\
\text { Determinants of corporate branding in the B2B context: } \\
\text { - main constituents of a corporate brand to generate tangible and intangible brand value in } \\
\text { a B2B context; and } \\
\text { - tangible and intangible brand benefits and whether they influence relationship initiation } \\
\text { and management practices in a B2B context. }\end{array}$} \\
\hline
\end{tabular}


Table 2: Summary of findings

\begin{tabular}{|c|c|c|c|c|c|c|}
\hline Themes & \multicolumn{2}{|c|}{ IBM } & \multicolumn{2}{|c|}{ Ogilvy } & \multicolumn{2}{|c|}{ UPS } \\
\hline Interviewers & Interviewee 1 & Interviewee 2 & Interviewee 1 & Interviewee 2 & Interviewee 1 & Interviewee 2 \\
\hline $\begin{array}{l}\text { Corporate personality and } \\
\text { corporate identity (philosophy, } \\
\text { vision, value and } \\
\text { positioning) elements reinforcing } \\
\text { the corporate brand }\end{array}$ & $\begin{array}{l}\text { Brand } \\
\text { personality; } \\
\text { innovative, } \\
\text { trustworthy, } \\
\text { mature } \\
\text { Logo / } \\
\text { typography } \\
\text { Product } \\
\text { designs }\end{array}$ & $\begin{array}{l}\text { Brand } \\
\text { personality; } \\
\text { innovative, } \\
\text { trustworthy } \\
\text { Logo } \\
\text { Product } \\
\text { designs }\end{array}$ & $\begin{array}{l}\text { Creator's } \\
\text { persona; } \\
\text { exciting, } \\
\text { creative, } \\
\text { innovative } \\
\text { Emotional } \\
\text { associations } \\
\text { through } \\
\text { slogans, } \\
\text { maxims etc. }\end{array}$ & $\begin{array}{l}\text { Creator's } \\
\text { persona; } \\
\text { exciting, } \\
\text { creative } \\
\text { Logo / } \\
\text { typography }\end{array}$ & $\begin{array}{l}\text { Brand } \\
\text { personality; } \\
\text { innovative, } \\
\text { trustworthy } \\
\text { Logo } \\
\text { Colors } \\
\text { Slogans } \\
\text { Packaging }\end{array}$ & $\begin{array}{l}\text { Brand } \\
\text { personality; } \\
\text { trustworthy, } \\
\text { caring } \\
\text { Logo / } \\
\text { typography } \\
\text { Colors }\end{array}$ \\
\hline $\begin{array}{l}\text { Organizational culture } \\
\text { constituents supporting corporate } \\
\text { branding }\end{array}$ & $\begin{array}{l}\text { Reliability } \\
\text { Sustainability } \\
\text { Innovation } \\
\text { Quality }\end{array}$ & $\begin{array}{l}\text { Reliability } \\
\text { Innovation } \\
\text { Leadership } \\
\text { Quality }\end{array}$ & $\begin{array}{l}\text { Customer } \\
\text { orientation } \\
\text { Creativity } \\
\text { Flexibility / } \\
\text { adaptability }\end{array}$ & $\begin{array}{l}\begin{array}{l}\text { Customer } \\
\text { orientation }\end{array} \\
\text { Creativity } \\
\text { Sustainability } \\
\text { Quality }\end{array}$ & $\begin{array}{l}\text { Reliability } \\
\text { Sustainability } \\
\text { Innovation } \\
\text { Quality }\end{array}$ & $\begin{array}{l}\text { Reliability } \\
\text { Sustainability } \\
\text { Quality }\end{array}$ \\
\hline $\begin{array}{l}\text { Key influencers of corporate } \\
\text { branding }\end{array}$ & $\begin{array}{l}\text { Customers } \\
\text { Suppliers }\end{array}$ & $\begin{array}{l}\text { Customers } \\
\text { Suppliers }\end{array}$ & $\begin{array}{l}\text { Customers } \\
\text { Governments }\end{array}$ & $\begin{array}{l}\text { Customers } \\
\text { Secondary }\end{array}$ & $\begin{array}{l}\text { Customers } \\
\text { Secondary }\end{array}$ & Customers \\
\hline
\end{tabular}




\begin{tabular}{|c|c|c|c|c|c|c|}
\hline & $\begin{array}{l}\text { Secondary } \\
\text { stakeholders } \\
\text { (e.g. NGOs, the } \\
\text { media) and } \\
\text { some primary } \\
\text { stakeholders } \\
\text { such as } \\
\text { potential } \\
\text { customers } \\
\text { through the } \\
\text { influence of } \\
\text { existing } \\
\text { customers }\end{array}$ & & $\begin{array}{l}\text { and regulators } \\
\text { as secondary } \\
\text { stakeholders }\end{array}$ & $\begin{array}{l}\text { stakeholders } \\
\text { (e.g. NGOs, the } \\
\text { media) and } \\
\text { some primary } \\
\text { stakeholders } \\
\text { such as } \\
\text { potential } \\
\text { customers } \\
\text { through the } \\
\text { influence of } \\
\text { existing } \\
\text { customers }\end{array}$ & $\begin{array}{l}\text { stakeholders } \\
\text { (e.g. NGOs, the } \\
\text { media) and } \\
\text { some primary } \\
\text { stakeholders } \\
\text { such as } \\
\text { potential } \\
\text { customers } \\
\text { through the } \\
\text { influence of } \\
\text { existing } \\
\text { customers }\end{array}$ & \\
\hline $\begin{array}{l}\text { The tangible brand values in a } \\
\text { B2B context as main constituents } \\
\text { of a corporate brand }\end{array}$ & $\begin{array}{l}\text { Competence } \\
\text { (i.e. operational } \\
\text { capability) } \\
\text { Assurance (e.g. } \\
\text { assured code of } \\
\text { conduct, } \\
\text { guarantees) } \\
\text { Economic (i.e. } \\
\text { market share, } \\
\text { profitability) }\end{array}$ & $\begin{array}{l}\text { Competence } \\
\text { (i.e. operational } \\
\text { capability) } \\
\text { Assurance (e.g. } \\
\text { assured code of } \\
\text { conduct, } \\
\text { guarantees) }\end{array}$ & $\begin{array}{l}\text { Competence } \\
\text { (i.e. operational } \\
\text { capability) } \\
\text { Assurance (e.g. } \\
\text { assured code of } \\
\text { conduct, } \\
\text { guarantees) }\end{array}$ & $\begin{array}{l}\text { Competence } \\
\text { (i.e. operational } \\
\text { capability, } \\
\text { creativity) }\end{array}$ & $\begin{array}{l}\text { Competence } \\
\text { (i.e. operational } \\
\text { capability) }\end{array}$ & 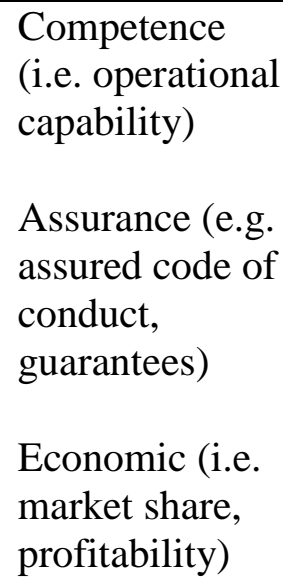 \\
\hline $\begin{array}{l}\text { The intangible brand values in a } \\
\text { B2B context as main constituents } \\
\text { of a corporate brand }\end{array}$ & $\begin{array}{l}\text { Brand } \\
\text { recognition }\end{array}$ & $\begin{array}{l}\text { Brand name } \\
\text { Brand image }\end{array}$ & $\begin{array}{l}\text { Brand name } \\
\text { Brand image }\end{array}$ & $\begin{array}{l}\text { Brand } \\
\text { recognition }\end{array}$ & $\begin{array}{l}\text { Brand image } \\
\text { and reputation }\end{array}$ & $\begin{array}{l}\text { Brand } \\
\text { recognition }\end{array}$ \\
\hline
\end{tabular}




\begin{tabular}{|c|c|c|c|c|c|c|}
\hline & $\begin{array}{l}\text { Brand name } \\
\text { Brand image } \\
\text { and reputation } \\
\text { Brand recall } \\
\text { Brand } \\
\text { associations } \\
\text { Brand } \\
\text { transferability }\end{array}$ & $\begin{array}{l}\text { and reputation } \\
\text { Brand recall } \\
\text { Brand } \\
\text { transferability }\end{array}$ & $\begin{array}{l}\text { and reputation } \\
\text { Brand recall } \\
\text { Brand } \\
\text { associations } \\
\text { Brand } \\
\text { transferability }\end{array}$ & $\begin{array}{l}\text { Brand name } \\
\text { Brand image } \\
\text { and reputation }\end{array}$ & $\begin{array}{l}\text { Brand recall } \\
\text { Brand } \\
\text { associations }\end{array}$ & $\begin{array}{l}\text { Brand name } \\
\text { Brand image } \\
\text { and reputation } \\
\text { Brand recall } \\
\text { Brand } \\
\text { associations }\end{array}$ \\
\hline $\begin{array}{l}\text { The role of brand value in } \\
\text { relationship initiation and } \\
\text { management / maintenance }\end{array}$ & $\begin{array}{l}\text { Brand name } \\
\text { and brand } \\
\text { recall benefit } \\
\text { relationship } \\
\text { initiation } \\
\text { Brand image } \\
\text { and reputation } \\
\text { benefit } \\
\text { relationship } \\
\text { initiation and } \\
\text { management } \\
\text { Brand } \\
\text { transferability } \\
\text { benefits } \\
\text { relationship } \\
\text { initiation }\end{array}$ & $\begin{array}{l}\text { Brand name } \\
\text { and brand } \\
\text { recall benefit } \\
\text { relationship } \\
\text { initiation } \\
\text { Brand image } \\
\text { and reputation } \\
\text { benefit } \\
\text { relationship } \\
\text { initiation and } \\
\text { management } \\
\\
\text { Brand } \\
\text { assurance } \\
\text { benefits } \\
\text { relationship } \\
\text { initiation and }\end{array}$ & $\begin{array}{l}\text { Brand image } \\
\text { and reputation } \\
\text { benefit } \\
\text { relationship } \\
\text { initiation and } \\
\text { management } \\
\text { Brand } \\
\text { assurance } \\
\text { benefits } \\
\text { relationship } \\
\text { initiation and } \\
\text { management } \\
\text { Brand } \\
\text { competence } \\
\text { benefits } \\
\text { relationship } \\
\text { management }\end{array}$ & $\begin{array}{l}\text { Brand name } \\
\text { and brand } \\
\text { recall benefit } \\
\text { relationship } \\
\text { initiation } \\
\text { Brand image } \\
\text { and reputation } \\
\text { benefit } \\
\text { relationship } \\
\text { initiation and } \\
\text { management } \\
\text { Brand } \\
\text { assurance } \\
\text { benefits } \\
\text { relationship } \\
\text { initiation and } \\
\text { management }\end{array}$ & $\begin{array}{l}\text { Brand image } \\
\text { and reputation } \\
\text { benefit } \\
\text { relationship } \\
\text { initiation and } \\
\text { management } \\
\text { Brand } \\
\text { assurance } \\
\text { benefits } \\
\text { relationship } \\
\text { initiation and } \\
\text { management } \\
\text { Brand } \\
\text { competence } \\
\text { benefits } \\
\text { relationship } \\
\text { management }\end{array}$ & $\begin{array}{l}\text { Brand image } \\
\text { and reputation } \\
\text { benefit } \\
\text { relationship } \\
\text { initiation and } \\
\text { management } \\
\text { Brand } \\
\text { assurance } \\
\text { benefits } \\
\text { relationship } \\
\text { initiation and } \\
\text { management }\end{array}$ \\
\hline
\end{tabular}




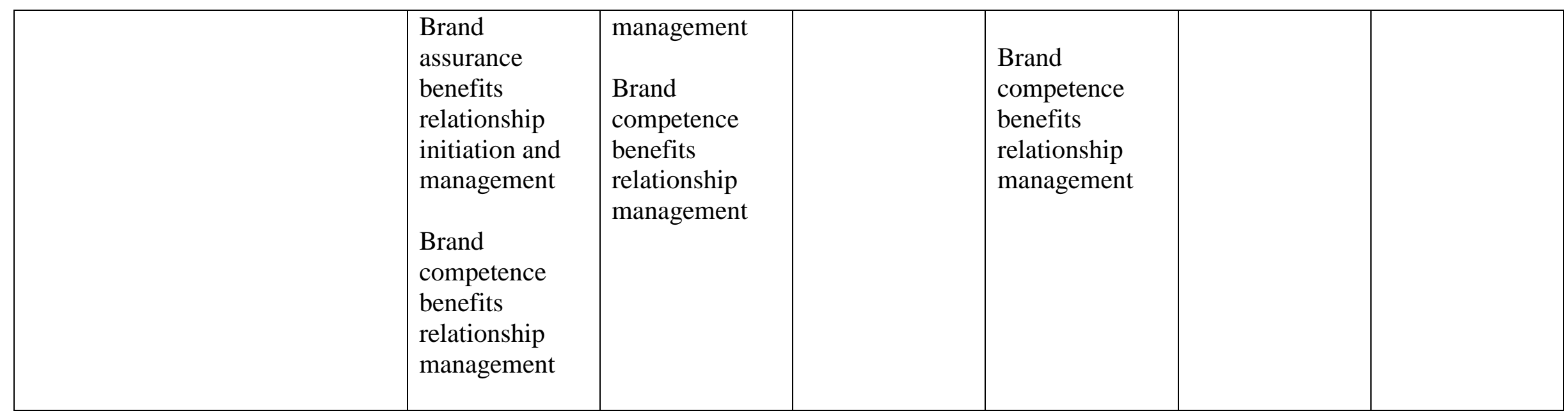


Figure 1: The proposed Model

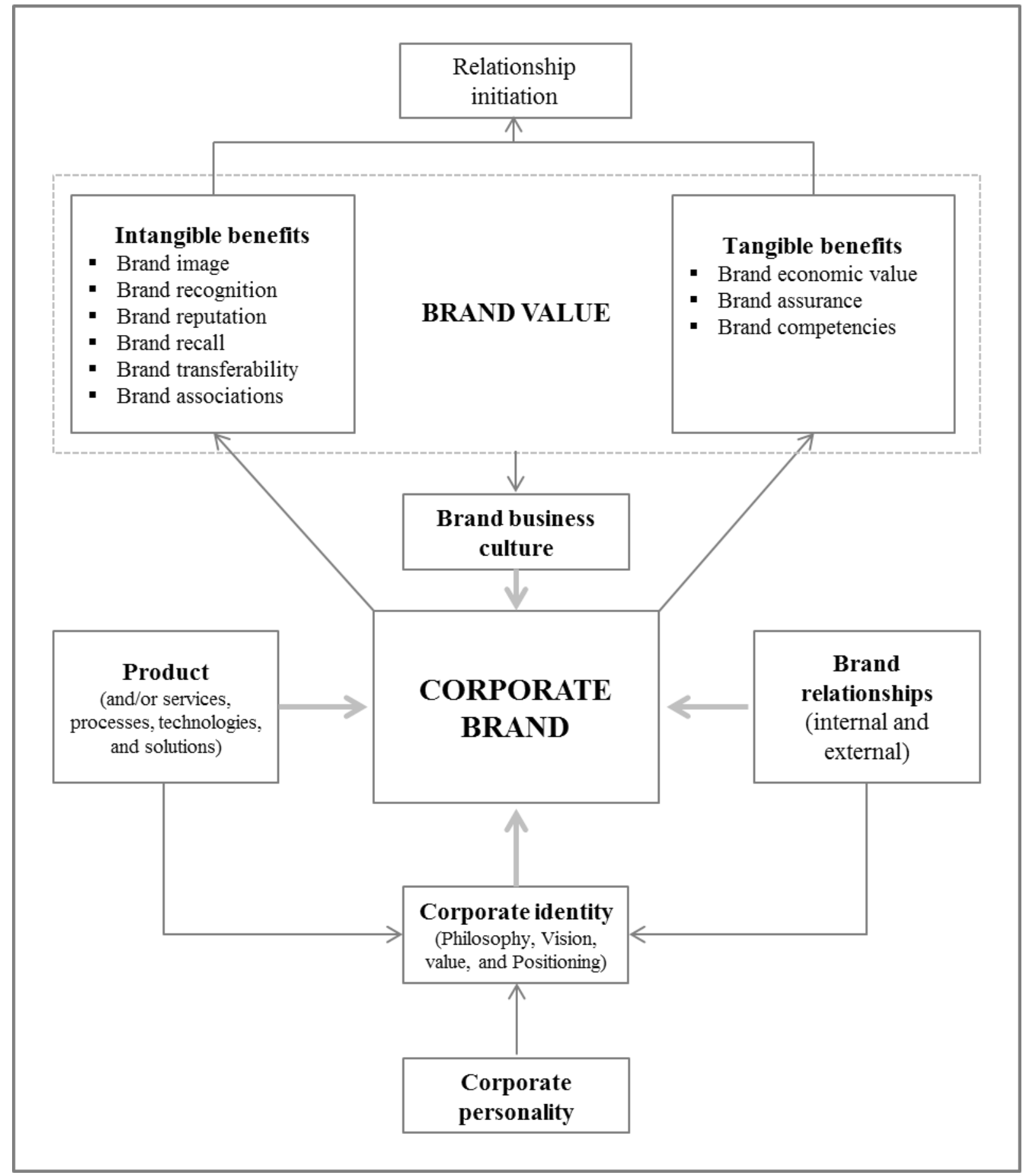

